Portland State University

PDXScholar

\title{
Expanding responsibilities and shifting demands : an analysis of the effects of migration and employment on immigrant women's negotiating power in the household
}

Kerry Greer

Portland State University

Follow this and additional works at: https://pdxscholar.library.pdx.edu/open_access_etds

Part of the Demography, Population, and Ecology Commons Let us know how access to this document benefits you.

\section{Recommended Citation}

Greer, Kerry, "Expanding responsibilities and shifting demands : an analysis of the effects of migration and employment on immigrant women's negotiating power in the household" (2006). Dissertations and Theses. Paper 3922.

https://doi.org/10.15760/etd.5806

This Thesis is brought to you for free and open access. It has been accepted for inclusion in Dissertations and Theses by an authorized administrator of PDXScholar. Please contact us if we can make this document more accessible: pdxscholar@pdx.edu. 


\section{THESIS APPROVAL}

The abstract and thesis of Kerry Greer for the Master of Science in Sociology was presented June 13, 2006, and accepted by the thesis committee and the department.

COMMITTEE APPROVALS:

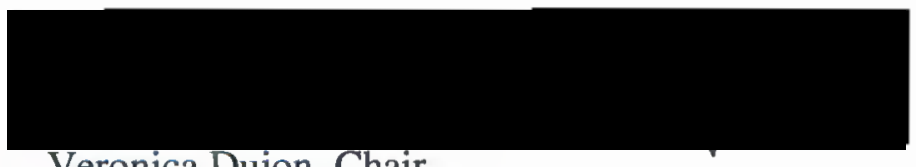

Veronica Dujon, Chair

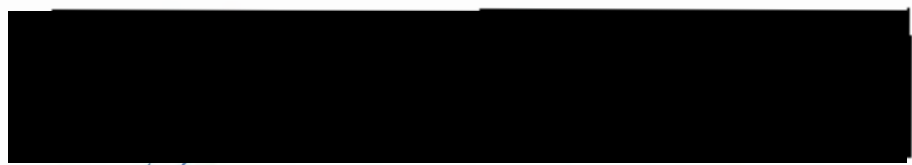

Johanná Brenner

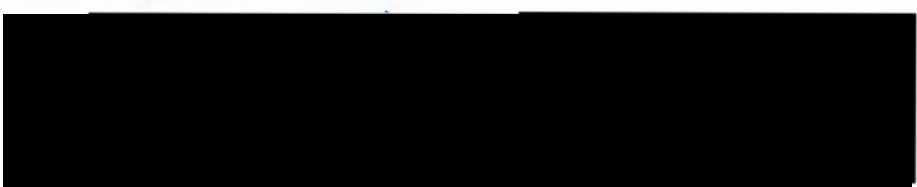

Melánie Arthlur

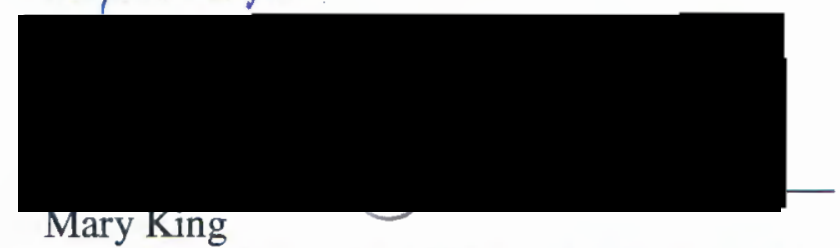

Representative of the Office of Graduate Studies

DEPARTMENT APPROVAL:

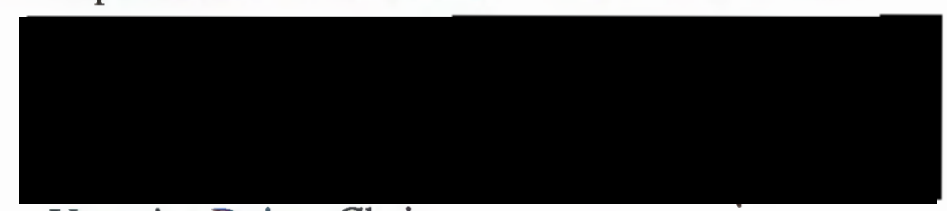

Veronica Dujon, Chair

Department of Sociology 


\begin{abstract}
An abstract of the thesis of Kerry Greer for the Master of Science in Sociology presented June 13, 2006.
\end{abstract}

Title: Expanding Responsibilities and Shifting Demands: An Analysis of the Effects of Migration and Employment on Immigrant Women's Negotiating Power in the Household

This study's objective was to examine the affect that migration and employment have on immigrant women's negotiating position within the household. Depth interviews were conducted with nine women who migrated to Portland, Oregon from Ethiopia or Eritrea. Women were encouraged to share a narrative history of their migration and employment experience. These interviews were analyzed to answer three primary questions: Who are immigrant women supporting through their participation in the paid labor market? How do women utilize gain access to employment opportunities and what strategies do women use once employed to meet competing demands on them at work and in the household? And finally, to what extent do women maintain control over their income and influence household decisions? This study found that women, particularly women who migrate prior to marriage, support natal households more than women who migrate after marriage. Women use social networks to find information about jobs, and once employed use an array of strategies 
to meet domestic demands. These strategies include joining households with other women to share household labor, finding employment opportunities that allow them to care for children while working, and having their mothers come to care for small children. Women who have recently married and have lived in the United States a short amount of time are most likely to express desire to maintain control over their income, while women who have lived in the United States for a longer time are more likely to pool their income with their husbands. Many women felt that they had an equal influence in household decisions as their husbands, but little evidence was provided that this was the case. Instead this study concludes that working outside of the home increases the perceived contribution that women make to the household leads to their empowerment and improves their negotiating position. 
' EXPANDING RESPONSIBILITIES AND SHIFTING DEMANDS: AN ANALYSIS OF THE EFFECTS OF MIGRATION AND EMPLOYMENT ON IMMIGRANT WOMEN'S NEGOTIATING POWER IN THE HOUSEHOLD

by

KERRY GiREER

A thesis submitted in partial fulfillment of the requirements for the degree of

MASTER OF SCIENCE

in

SOCIOLOGY

Portland State University

2006 
thanks, geo 


\section{Acknowledgements}

First and foremost, I would like to acknowledge the women who gave freely of themselves and sat down with me to share so much of their life history. The women who were interviewed for this thesis worked hard to provide me with an understanding of their experience and to bridge a cultural divide. Their generosity of spirit helped propel this project forward. I would often feel chagrin during interviews when women would tell me that they had been working since 6 a.m. and would be continuing to work until I had gone to bed. In this context, their time was so valuable that I am forever in their debt.

I would like to express my gratitude to my thesis committee, Dr. Veronica Dujon, Dr. Melanie Arthur, Dr. Johanna Brenner, and Dr. Mary King. Teaching me in several different capacities throughout my graduate career, I am especially grateful for their patience and willingness to work within the time constraints that this project entailed.

Finally I want to thank my husband for supporting me so graciously. His willingness to value my academic aspirations is a great gift he has given me. 


\section{TABLE OF CONTENTS}

PAGE

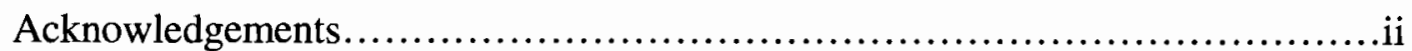

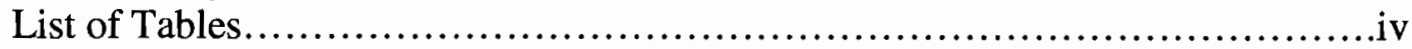

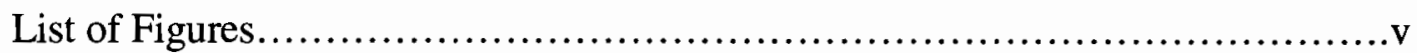

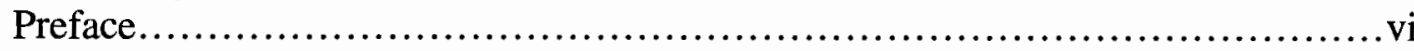

Chapter

I. Introduction.............................................................

II. Literature Review....................................................

Social Networks.............................................. 13

Social Location.................................................16

Household Modeling and Bargaining Position......................19

Agency and Empowerment.....................................24

Previous Studies .............................................29

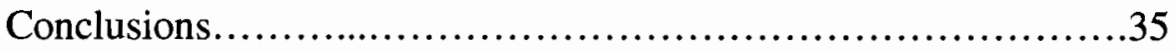

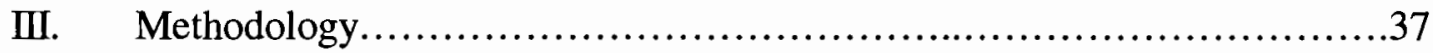

Sample Characteristics........................................38

Data Collection: Depth Interviews ..............................41

The Research Process.........................................42

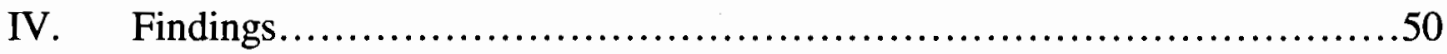

Migration and Natal Household Relations..........................50

Employment and Social Networks................................56

Income and Empowerment.....................................62

Conclusion.................................................69

V. Discussion and Conclusions...........................................71

Summary of Findings......................................... 71

Suggestions for Future Research.................................74

Limitations of Current Research...................................75

Works Cited........................................................... 77

Appendix A: Voluntary and Informed Consent...............................80 


\section{LIST OF TABLES}

Table 1: Sample Characteristics..........................................39 


\section{LIST OF FIGURES}

Figure 1: Immigrant Flows From Ethiopia and Eritrea to the U.S. 1995-2005....... 7 


\section{PREFACE}

\section{Ethiopia and Eritrea}

Many of the women that were interviewed for this study referred to specific events that occurred in Ethiopia and Eritrea. Because war and conflict were major forces in motivating individuals and families to leave their homeland and come to the United States, I found that it was necessary to review the recent history of conflict in this region. The following is a short overview of the recent history of Ethiopia and Eritrea.

The war between Ethiopia and Eritrea was essentially a fight for independence by Eritrea. Many Ethiopians I spoke with claimed that there was no difference between Ethiopians and Eritrean, and that the war had been unnecessary, while many Eritreans claimed that the differences between the two nationalities were severe. This was in contrast to the differences between ethnic groups in Ethiopia and Eritrea. These differences were highlighted here in Portland, but many claimed that they were less important in their homeland. Because this war was so pervasive and so much a part of the story that women shared, particularly in accounting for why they emigrated and why they worked to send money to their family members who remained in Ethiopia or Eritrea, what follows is a short overview of the history of the war between Ethiopia and Eritrea and a brief description of the three dominant ethnic groups in this region.

Ethiopia has never been successfully colonized, although the Italians tried in 1936, and failed. During World War II Ethiopia declared war on Germany, Italy, and Japan and at the end of the war developed diplomatic relations with the Soviet Union. As part of the agreements after World War II, Haile Selassie, then the leader of 
Ethiopia, met with U.S. President Roosevelt and was given permission to annex Eritrea, itself a British colony, in order to ensure access to seaports for economic development. This transference of sovereignty occurred in 1952 (Shinn and Ofcansky, 2004). By 1961, Eritreans began an armed struggle against Ethiopia to gain independence. During this time, the United States, in exchange for the right to build a military base in Ethiopia, supplied Ethiopia with military arms and training until 1977, when human rights violations and an escalating war with Eritrea resulted in the US stopping arms shipments and closing the US consulate in Asmara, Eritrea as well as removing US personnel from Ethiopia.

Ethiopia then turned to the Soviet Union for economic and technical assistance. By 1979 Ethiopia had collectivized its agricultural sector, and instituted centralized control of the economy. The positive outcome of this was an increase in access to education, especially for women. It was not until 1992 that Ethiopia was removed from the U.S. "Marxist-Leninist List," making them qualified to receive preferred trading status with the US.

In the late 1980's, Eritrea's armed struggle for independence was recognized by outside interests and the International Negotiating Network, chaired by former U.S. president Jimmy Carter, pressured Ethiopia to transfer power to Eritrea. Finally, in 1993, Eritrea achieved independence. Since then, there have been ongoing border disputes between the two countries, escalating in the late 1990's into war, which ended officially in 2000 , although there has been continued violence at the border.

Ethiopia and Eritrea are comprised of three primary groups of people: the Oromo, the Amharic, and the Tigre. In terms of religion, the Oromo tend to be equally 
divided between Ethiopian Orthodox, also referred to as Coptic Christians, and Muslim. The Amharic the Tigre are generally Ethiopian Orthodox. The Tigre peoples are mostly in Eritrea but also in northern Ethiopia, while the Amharic and Oromo live primarily in Ethiopia. 


\section{Chapter I}

\section{INTRODUCTION}

The purpose of this research is to examine how migration and employment affect women's ability to negotiate within the context of changing gender roles in immigrant households. Over the course of six months nine in-depth interviews were conducted with immigrant women from Ethiopia and Eritrea who were living in Portland, Oregon. Over the course of these interviews women shared similar stories of migration to the United States and having to quickly adjust to new roles and to meet new expectations. This research focuses on how changes in structural context affect women's agency within the household. As women have engaged in paid labor, social scientists have theorized that earning an income improves the status of women in the household and leads them to have greater decision making power and control over their lives (Safilios-Rothschild 1990, Wolf 1992, Kabeer 2000). However, while the social structures that exist in the United States support women in exercising control over their earnings, women who migrate to the United States from Ethiopia or Eritrea bring with them a set of norms and values that reflect a culture in which women have less power.

The objective of his research project is to examine how nine subjective accounts of migration and employment can help to provide a deeper understanding of how immigrant women define their empowerment and how the experiences of migration and working affect women's bargaining position within the household. Empowerment refers to a person's ability to take control over her life and make decisions for herself. 
The household exists within the context of the community and the state, and within broad social, political, and economic structures that both provide opportunities and places constraints on the possible strategies that households can utilize for survival. The household is an important location for understanding the interaction between agency and structure. Households are locations in which individuals meet and mediate cultural norms and values while developing new cultural meanings that, in turn, influence the norms and values that regulate their behavior. But within households, the choices that are made reflect a set of cultural norms and expectations and, often if not always, this puts some individuals in the position of having more power over these decisions than others. This power imbalance falls along lines of gender and age.

Over the course of the past twenty to fifty years the demand in the labor market for female labor has increased. Women are entering the labor force to secure access to money that can be used to purchase the food and goods that the household needs for survival. There is a tendency to characterize women's entrance into the labor market as an either/or proposition. Either employment is a way of increasing female empowerment or it is a way that capitalism is exploiting another group of people. Rather than approach this as a rigid dichotomy, this research will take as its starting point that there are some advantages of employment and there are some disadvantages, but these advantages and disadvantages need to be understood from the perspective of the women who are working and an effort needs to be made to understand how work and migration are changing their lives. 
Gender is not the only subjugating force in society. Class, race, and ethnicity are also important. If gender is to be understood as a set of attitudes and beliefs about behavior that are attributed to a particular sex, then gender, class, race and ethnicity share the distinction of being mediated social locations, which is a departure from the mediated class location that Eric Wright describes as existing when one's occupational status contradicts his or her class location (1997). Women in this study occupy a mediated social location in the sense that their gender, class, race and ethnicity have very different cultural meanings in the context of their household compared to the cultural meanings they have when they are looking for work, taking their children to school, or doing any of the myriad things that women do in public on a daily basis. An Eritrean or Ethiopian woman working in the United States might have earned enough money working as a clerk to place her in an upper class household in her native country, but here her low occupational status places her in the working class. Likewise, a woman from Ethiopia or Eritrea might consider herself Amharic or Oromo, two of the many ethnic identities that are the predominant way people in Ethiopia and Eritrea identify themselves, but in the United States they are identified as black, African or African-American. And, finally, migrants carry with them traditional concepts of gender, and these concepts are often challenged when they are exposed 0 Western conceptions of gender. These contradictions need to be contextualized in order to gain a deeper understanding of how immigrant women from Ethiopia and Eritrea construct identities. 


\section{Research Questions}

This study analyzes several questions, decisions and processes that center on the junction of structure and agency, specifically at the location of the household. The first empirical question that this research addresses is, who are women supporting through their labor? In order to answer this question, this research will examine how and by whom the decision to emigrate was made. The majority of women in this study emigrated prior to getting married and all of the women in this study had family and kin that remained in Ethiopia or Eritrea that depended upon them to send remittances. These remittances have become an important source of support for households in the developing world where a lack of economic development and ongoing war has limited the ability of households to support themselves through subsistence activities. Sending a daughter or wife to work in the First World has been identified as a survival strategy among Third World households.

The second major empirical question examines women's experiences in the labor market. Specifically, how do women find employment, and once employed, what strategies do women identify as helping them meet the competing demands of household labor and employment? The type of employment that immigrants find is dependent in part on their access to social networks, which provide information about job opportunities. Women have different employment constraints than men because of their domestic responsibilities. Occupational segregation along gender lines means that the labor market that women access is different than the labor market than men access. For these reasons it is expected that women will use a predominantly female social network to find employment. Gendered social networks serve purposes beyond 
providing information regarding employment opportunities, they are also used by women to develop strategies that meet the domestic obligations of caring for a husband and children. These networks enforce cultural norms and values, but this research investigates whether they also can act as support systems through which women can confront and challenge the norms and values that result in women's oppression.

The third major empirical question examines to what extent women feel that they are able to maintain control over their income and influence household decisions? The ability to maintain control over income and to influence household decisions is taken in this study to be a reflection of female empowerment. Income refers to the wages that a person earns from employment or investment. Previous research has indicated that women do not necessarily maintain control over their income and that men, both husbands and fathers, often either manage the income or pool it with household income, thus securing their right to control how it is spent (SafiliosRothschild 1990, Gamburd 2000).

This study seeks to understand the extent to which women feel that they have had control over the decision to emigrate and to engage in paid labor and how these experiences have impacted t'ieir ability to maintain control over income and influence household decisions. By eliciting subjective accounts of women's experiences of migration and employment, this study explores the cultural meaning of these events and gains insight into how these experiences do or do not contribute to a sense of empowerment. 


\section{The Population: An Overview}

People from both Ethiopia and Eritrea are included in this study with the understanding that, although in many ways they are culturally distinct, historically the fate of one country has been closely tied with the fate of the other. This decision, made early on in the research process, proved valuable, as many women reported that during the war between Ethiopia and Eritrea their families moved back and forth between the two countries to avoid the worst of the violence. As a result, some early comers to the United States consider themselves to be Ethiopian even though they had grown up in what is geo-politically Eritrea.

Census data indicates that immigrants from Africa are steadily increasing, from $3.9 \%$ of all immigrants to the United States in the 1990 's to $6.6 \%$ of all immigrants in 2004 (U.S. Yearbook of Immigration Statistics 2004). Census data shows that after Nigerians, Ethiopians compete with Egyptians and Ghanaians for being the largest nationality of people migrating to the United States from the African continent (U.S. Yearbook of Immigration Statistics 2004). In addition, Ethiopians and Eritreans together composed about one-tenth of all asylum seekers in 2004 (U.S. Yearbook of Immigration Statistics 2004). Ethiopia ranks fourth on the African continent in the number of refugees that have come to the United States in the past ten years (U.S. Yearbook of Immigration Statistics 2004). Finally, Ethiopians are third to Nigerians and Egyptians in the number of naturalizations that occur in the United States (U.S. Yearbook of Immigration Statistics 2004).

The number of people emigrating from Eritrea is far smaller, although this is to be expected since the population of Ethiopia is estimated to be about 75 million people 
and Eritrea's population is estimated to be close to 5 million (CIA Factbook 2006). Both countries saw a decline in emigration with the end of the war in 2000 , and this decline was more pronounced in Eritrea (Table 1). The number of Eritreans migrating to the United States has declined from just less than 1,000 in 1995 to a low of 326 on the eve of a peace agreement in 1999 before rising to a current level of 673 in 2004 (U.S. Yearbook of Immigration Statistics 2004). In terms of refugees, there has been a relatively steady increase, with the exception of 2002 and 2003, in the number of Eritreans who have entered the United States as refugees (U.S. Yearbook of Immigration Statistics 2004). The number of asylum seekers from Eritrea and

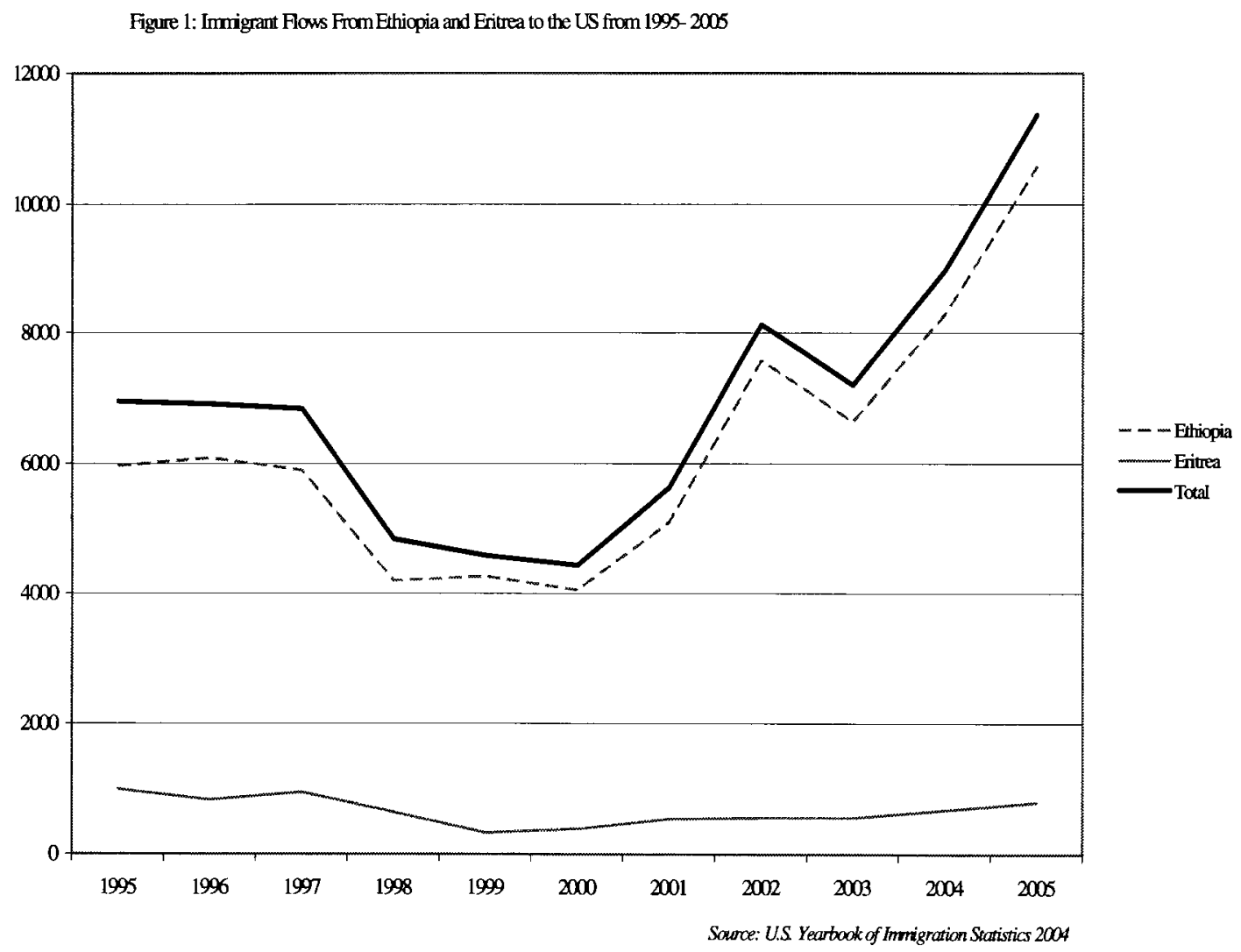


Ethiopia increased steadily until 2000 , when the numbers began to decline, suggesting that the need for asylum decreased after a peace agreement was reached.

While immigrants are free to move once they arrive, the census data indicate that an increasing number of immigrants from all over the world are moving to Oregon. The number of immigrants that intend to reside in Oregon has increased from fewer than 5,000 people in 1995 to approximately 8,500 in 2004 (U.S. Yearbook of Immigration Statistics 2004). Anecdotal evidence further supports that Portland in particular is becoming a destination for people emigrating from East Africa.

Census data on specific nationalities of people are not available for regional geographic areas, and after speaking with different community leaders and shopkeepers it remains unclear how many Ethiopians and Eritreans live in Portland, Oregon, although there is agreement that the numbers are increasing steadily. Estimates of the number of Ethiopians living in Portland vary from 3,000 to 13,000 with 9,000 being the most common estimate. As for Eritreans, the estimates are much smaller, typically between one and two thousand. Immigrants who came to Portland ten or more years ago reported that the numbers have increased significantly, and those who reported coming to Portland in the past five years agreed that there was a viable community of Ethiopians and Eritreans already established in Portland, although not as large as populations in cities such as Washington, D.C. or Oakland, California. These more recent immigrants reported that Portland was becoming known for its population of Ethiopians and Eritreans and that this was one of the reasons they had moved here as opposed to another U.S. city. This suggests that the population of Ethiopians and Eritreans in Portland will continue to grow. 
In Portland, there is a locus of Ethiopian and Eritrean owned businesses in Northeast Portland, specifically along the Northeast Martin Luther King Junior Boulevard and to a lesser extent on Northeast Broadway. The 2000 U.S. Census data suggests that nearly half of Portland's African-born population lives in the neighborhoods adjacent to these businesses (Chuang 2003). There are several Ethiopian and Eritrean owned restaurants and markets in the vicinity as well as several churches and community centers that cater to the different ethnicities that comprise the Ethiopian and Eritrean populations. The Oromo are by far the most visibly organized; they have a well-organized community center as well as active and growing churches and mosques. The Eritreans also have a community center, although it does not have the same level of activity as the Oromo community center and instead primarily serves as a place where celebrations and holidays are held. The Amharas, as a distinct ethnic group, do not have a community center, although the Ethiopian Orthodox church organizes many cultural activities.

An examination of the local paper, The Oregonian, provides further evidence of the increasing community presence of Ethiopians and Eritreans. Several articles cover an array of subjects including Ethiopian and Eritrean children who are excelling at school and gaining admittance to top U.S. universities (Chestnut 2003). Other articles examine the racial relationships between African immigrants and AfricanAmericans; offer assessments of Ethiopian and Eritrean owned businesses; and interview community and religious leaders to gain a sense of how the community is fitting in within the broader community (Chuang 2002, 2003, 2004, Brink 2005). 
These articles suggest that the growing presence of Ethiopians and Eritreans is having an impact on how the community operates and what it will look like in the future.

\section{Thesis Overview}

This thesis is organized in four sections. The following chapter reviews theories of migration, social networks, household modeling, and female agency. This review of the literature creates a context for understanding migration and employment as an adaptive response to economic uncertainty. Economic development has increased the reliance on the paid work of women, transforming their position in the household, both in the country of origin and the place of destination. Theories are presented that provide a framework for examining how structural changes have affected women's agency and women's negotiating position within the household. Empirical studies that share key features with this research are also considered.

Chapter three outlines the methodology, highlighting the research question, and the research design of the current research. Because the goal of this research was to gain an understanding of how women construct meaning and negotiate their identity amidst changing social norms and values, a qualitative method designed to elicit narrative histories of women's experiences was utilized. Chapter four presents an analysis of the data and selected quotations from the interviews that illustrate several of the major themes that emerged throughout the research process. The rich narratives women shared regarding their migration and employment experiences are explored and analyzed. Of particular interest was the discovery that one arena where women struggled the most in terms of household negotiations was in the transference of remittances to their families who had remained in their home country. Chapter five 
situates this research in the theoretical framework developed in the literature review. The main findings that are elaborated on, followed by a discussion of the implication of these findings, suggested areas for future research and the limitations of the current research. 


\section{Chapter II}

\section{LITERATURE REVIEW}

This research draws on sociological research regarding social networks, social location, and alternative approaches to modeling household bargaining position. The purpose of this review of the literature is to provide a theoretical argument that women's role in the global economic structure has changed radically, resulting in increased pressure on women to provide for households by engaging in paid labor outside of the home. One strategy that households have used to ensure survival has been for either individual household members to emigrate or for entire households to emigrate in search of employment. Social networks have emerged as a key area in understanding the relationship between immigrants and the communities that they leave behind. Social networks act as conduits for the flow of information and remittances, providing a system of support for the community and a cultural connection for the immigrant. Women are increasingly the household members who are migrating in search of employment and supporting their natal households while also working to support new households in the destination country. Women's contribution to household economy has not always received adequate attention in social research however, and feminist theorists have long contended that there is a need to focus on household economy from a gendered perspective. This literature review explores these theories and focuses on developing a context for understanding how changes in structure affect the formation of identity, specifically the identity of class and gender location (Sacks 1989, Zavella 1991). 
Households emerged as a unit of analysis in the 1950's, and in recent years have become important for providing the context for analyzing intra-household processes, conflicts, and dynamics, particularly from a feminist perspective (Wolf 1997). The household stands as the mediating institution where cultural norms and values are passed from one generation to another. This cultural transmission helps form an individual's class and gender identity. Class and gender represent two dimensions of an individual's social location. Social location refers to one's class, ethnicity, race, and gender identity and an argument is constructed in the following review of the literature that these identities are mediated by the experience of migration and employment, specifically for women. This mediated social location reflects the changes in structure that accompanies a woman's migration and can lead to increased agency and empowerment.

\section{Social Networks and Remittances}

Social networks connect the place of origin with the destination and create a way of transferring information, goods, and money between places (Hugo 1994, Castles and Miller 2003). Social networks are cultivated by family and kin networks and are a mechanism that helps to reinforce norms and values of the native country in a new context (Boyd 1989, Hugo 1994, Sassen 2003). Immigrants depend on social networks to gain access to information about a location before emigrating and to find employment once arriving in a new location. Because social networks provide a mechanism for social control, scholars have contributed the existence of these networks as factors that have contributed to the increased number of women 
immigrants (Wolf 1992, Gamburd 2000). It has been reasoned that social networks provide a sense of security to natal families, making it possible for women to emigrate who would otherwise not be allowed (Hugo 1994, Gamburd 2000, Sassen 2003).. This has been contributed to helping women get away from the direct influence of the family and providing women with an opportunity to develop a sense of autonomy and independence (Wolf 1992, Gamburd 2000). Furthermore, social networks have been identified as a key mechanism through which pressure can be placed on immigrants to ensure that remittances are forthcoming (Hugo 1994, Sassen 2003). These remittances have become an increasingly important supply of foreign currency in the developing world and the promise of remittances is an important motivating factor when households make the decision of who will migrate (Hugo 1994, Castles and Miller 2003, Sassen 2003).

In her study of remittances in Sri Lanka, Gamburd found that among married women, remittances were sent to husbands, since it is customary in Sri Lanka for a wife to become the property of her husband after marriage (2000). Married couples would often agree beforehand that the money would be used to buy land and to build a house, but in practice, Gamburd (2000) cites several cases where the money was misspent by the husband, and when the wife returned from her employment abroad, very little money was left. In contrast, Gamburd (2000) found that when unmarried women went abroad to work, the money that they sent to their family was used to improve not just their parents standard of living, but their own as well. 
There is evidence that women are maintaining transnational households with dependents remaining in the sending nation, relying on the transfer of remittances for survival, as new households are being established in the United States (Boyd 1989, Hondagneu-Sotelo 1999, Sassen 2000). This arrangement depends on family and community members to take care of dependent children and suggests an aspect to social networks that is primarily female since there is strong and long standing evidence that the responsibility for caring for children and maintaining a home falls upon women (Boyd 1989, Hondagneu-Sotelo 1999).

Sometimes cast as a form of social capital, access and control of networks determines the ability of new immigrants to survive and adapt in a destination (Hugo 1994, Castles and Miller 2003). Portes and Rumbaut (1996) argue that migration patterns to the United States follow a specific chronology starting with an initial generation of pioneer immigrants coming and settling, followed by family members and, as the network expands, friends and others who are able to make a claim on the social network that continues to evolve and grow in size and complexity. The initial pioneers, in this formulation, have access to capital and education and are able to translate skills and knowledge into business ventures and professional careers, or alternatively enter the workforce as wage earners (Portes and Rumbaut 1996). While this analysis does not explicitly exclude women, it does not account for the additional challenges that women encounter when migrating. For instance, women who migrate from developing countries often lack access to capital and education that would improve their ability to enter a professional career. Female immigrants are also 
accessing different kinds of employment and have to consider strategies for meeting domestic responsibilities while employed. This suggests a need for a gendered approach to social networks.

\section{Social Location}

A challenge in considering the social location in studies of immigrants, particularly female immigrants, is identifying a point in time when a person's social location is defined (Beneria and Roldán1987). On one hand, there is the tendency to argue that a woman's family defines her social location. Family of origin has a great deal of influence on the level of education that a person will receive, the types of opportunities that will be available, and the types of resources that will be made available to an individual (Benería and Roldán 1987). But after a woman immigrates, the impact of kin and family on social location lessens. Likewise, the meaning of race, ethnicity, gender and class changes when an individual moves from a region where the social, economic and political structures place different constraints on individuals.

Immigrant women can be conceived as occupying a space that exists between two different, and often conflicting, sets of identities. Wright defines direct class location as how “one's relationship to the process of exploitation shapes one's material interests" (1997:26). Women, who share the position of being subordinated to men and to capital, have historically been constrained by social structures that limit their material interests to the domestic sphere. As women have entered the labor market, their direct class location has shifted, and with this shift has come a change in the structures that constrain the choices that women have. This contradictory location, 
where a woman's identity is defined by her attachment to family and kin and by her experiences working in the world needs to be understood.

One approach that feminist scholars have taken for gaining an understanding of this mediated social location has been to examine the structures of pre-capitalist societies. Historically, pre-capitalist societies have been organized along conceptions of reciprocity and redistribution, which were reflected in an economic system that was subsistence-based and community-directed (Polanyi 1944). The rise of market economies depended on changes in norms and behaviors to reflect economic rationality, which is the desire to maximize utility according to a set of preferences and is the primary organizing principle in a capitalist economy (Benería 2003). Beneria argues that developing nations that are new to the forces of globalization have to reconsider behaviors and values that were developed in the context of subsistence production where market activity was more the exception than the norm (2003). This transition to capitalism involves the formation of a proletariat workforce, and changes the class composition of the society (Benería and Roldán 1987).

While this conceptualization provides a framework for considering the ways the economic system impacts social structures, Beneria argues that Polanyi failed to fully take into account how economic transformations and the corresponding changes in norms and behaviors affect women differently than men (Benería 2003). The rapid transition of women from marginal employment and subsistence production to becoming the backbone on which much of global production depends has impacted women's relationship to social, economic, and political structures as well as how 
women construct their social location. Under early capitalist models, particularly in England, women remained in the household and maintained responsibility for social reproduction (Benería and Roldán 1987). In peripheral capitalist states the evolution of capitalism has been different. Rather than utilizing male labor, Sassen argues that the globalization process has disempowered male wage earners and put women in the position of having to strategize to ensure household survival (Sassen 2003).

One way that women have responded to the increased demand that has been placed upon them to earn a wage has been to immigrate in search of work. Immigrant women participate in the labor market at much higher rates than prior to emigration (Pessar 1999). They also are just as prevalent as men in legal immigrant flows to the United States, Australia, Canada and Europe (Boyd 1989). This is partially a result of an increase in demand for female immigrant labor in the global North, where the effects of the global economy have replaced middle class households with a new household structure, which Sassen refers to as "professional household without a "wife"" (Sassen 2003). It is in these locations where jobs, which were once the domain of the middle class, are becoming increasingly devalued and are being replaced by a growing "serving class" of mostly female workers (Sassen 2003). For instance, work of caring for children and elderly members of society, taking care of household management activities such as food preparation and cleaning, as well as the growth in dependence on food that is prepared outside of the home are all jobs that are increasingly being done by immigrant workers. 
The existing literature on the effect that migration and employment have on gender identity has been contradictory (Espiritu 1999, Pessar 1999, Gamburd 2000). Some have argued that migration creates the context where women have greater access to employment, more control over earnings and greater control over household decisions (Espiritu 1999). Others have argued that migration changes gender dynamics while leaving asymmetries in power unchanged (Espiritu 1999). One area that has emerged as promising in terms of understanding what leads to female empowerment is research that has considered the class location of immigrants (Safilios-Rothschild 1990, Chen 1992, Min 1998, Espiritu 1999). This research has shown that class has an important impact on the improvement of women's social position, especially within the household, with women from professional class households maintaining more control over their income than women from working class households.

\section{Household Modeling and Bargaining Position}

Research that examines family survival strategies in developing countries highlights the importance of the households not only as the basic unit of social organization, but also as the traditional unit in which economic decisions are made (Salaf 1990, Hugo 1994, Sassen 2003). Feminist theorists have criticized considering households as locations where strategies for survival originate because the concept of household strategies misrepresents gender and generational power imbalances (Wolf 1997). For instance, the decision to send one member of a household to another location in search of work as a part of a household survival strategy is often made by senior members of the family, usually older males (Hugo 1994). But to suggest that 
this decision is made in a static context of uncontested patriarchy where males, and more specifically older males, have power over female household members underestimates the position of the household as a mediating location between the macro structures of economy, polity, and society and individual agency. It is within the broader context of legal, political, and economic structures that negotiations occur among household members and these negotiations affect the way resources are utilized and allocated among household members (Agarwal 1997, Kabeer 2000).

In developing a model of household behavior that was consistent with neoclassical economic theory, early theorists approximated household behavior based on expectations of individual behavior. Individuals were expected to act rationally with the goal of maximizing their utility in both their consumption preferences and in supplying their labor. Translating this concept to the household, theorists could not reconcile different preference ordering among different individuals within the household, so it was assumed that there was a natural tendency toward altruism in the family which allowed for the assumption of a joint welfare function that maximized aggregate household utility (Samuelson 1956). Later theorists altered this altruistic assumption to include the possibility that the head of the household acted as a benevolent dictator who would reflect the maximum household utility in his own ordered preferences (Becker 1981).

The concept of household utility maximization was developed by Becker (1981) who, with what is now known as New Household Economics or the Unitary Model of the Family, strengthened the altruistic assumption that Samuelson made by 
arguing that the complementary nature of male and female biological reproduction enforces a unity in preferences to the point where decisions of both household consumption and production are made in an effort to maximize the utility function of a single entity (Becker 1981). This means that decisions regarding the division of labor within the family would be made according to the concept of comparative advantage. This principle dictates that people will choose to engage in activities in which they are marginally more productive than another person. Over time, tasks become specialized and the margin widens as people become increasingly efficient in the tasks that they have specialized in - thus women stay home raising children and doing housework while men work outside of the home earning a wage (Becker 1981, Cherlin 2002).

This model, as well as variations of it that depend upon an assumption of either altruism or a benevolent dictator, has been routinely criticized (Folbre 1986, Sen 1990, Kabeer 1998,2000$)$. The majority of the criticism is centered on the failure of the model to provide a mechanism for evaluating the relative utility of individual household members. Because neo-classical economic theory does not allow for the subjective evaluations of utility from different individuals, the model assumes that utility is equally shared among all household members (Kabeer 1998, 2000). Equally powerful criticism is raised in acknowledgment that households, as analytic constructs, do not have the ability to make decisions, thus individuals are making decisions regarding how preferences are ordered and how resources are allocated. This implies that some of these individuals must have power over the other individuals in 
the household (Kabeer 1998, 2000). Typically these differences in power fall along lines of gender and age (Kabeer 1998, 2000).

While there is general agreement that the Unitary Model of the Family has significant flaws, alternatives are contested (Folbre 1986, Sen 1990, Kabeer 1998). Alternative models generally fall under the heading of "bargaining models" with variations occurring in the extent to which individuals cooperate. An exception is the non-cooperative model which assumes that individual members of a household operate in separate spheres where they implicitly divide labor based on social norms but still bargain over jointly shared goods and activities (Agarwal 1997, Kabeer 1998).

The basis for bargaining models is game theory, developed by Nash (1950). According to this theory, in its application to households, two household members bargain over pooled resources under a series of assumptions, including the assumption that both parties are fully informed (Agarwal 1997). The outcome of a bargaining negotiation, according to the strictest application of this theory, is determined by an individual's bargaining power, which is defined by his/her fallback position and is often assumed to be divorce (Agarwal 1997). Although a woman's fallback position is often more stigmatized than a man's and this can, in part, be captured in the model, critics of this sirict application of the theory argue that it ultimately fails to explain the actual process of bargaining and does not account for asymmetries in power due to both individual capabilities and cultural norms (Sen 1990, Agarwal 1997).

Sen developed a model of household bargaining that takes account of these deficiencies, providing a much more complete picture of the bargaining process 
(1990). His model, called Cooperative Conflicts, still uses the general framework of game theory but allows for more information to be utilized in predicting an outcome. Instead of referring to a fallback position strictly in terms of divorce or noncooperation, he allows for individual perceptions of well being to determine the fallback position. While this still allows for divorce, it also respects the effects that social norms can have on an individual's perception of choice. For instance, in societies where divorce is more stigmatized or an untenable choice, then to consider it as a real option is to fail to capture the real situation of the woman's bargaining position. This is especially the case if gender relations are compared within the context of households cross-culturally where different social norms influence the choices that women have.

In addition to considering individuals' perception of well being as a determinant of a fall back position, Sen takes the important step of acknowledging that perceived contributions to household resources are both personally and socially derived (1990). For instance, in societies where one form of work is more valued than another form of work, the person performing the more valued work will be perceived as contributing more to the overall welfare of the group and will have a more favorable bargaining position (Sen 1990). Sen identifies differences in education, ownership, patterns of employment, and training as contributing to a solidification of men's stronger bargaining position and argues that these differences are sustained over generations, continually strengthening men's bargaining position at the expense of women (1990). 


\section{Agency and Empowerment}

In her seminal paper "Bargaining with Patriarchy," Kandiyoti (1988) creates a framework for analyzing the factors within a household that contribute to the asymmetries in bargaining positions for men and women. By first constructing two models of the household, one of which has less of a patriarchal structure and is typical of much of sub-Saharan African and the other, which has more of a patriarchal structure and is common in the Middle East and Southeast Asia, Kandiyoti argues that women are operating within a normative framework of a dominant gender ideology that formulates their choices and determines their strategies for bargaining within their households. For instance, she argues that in sub-Sahara Africa women trade off polygyny for autonomy, working to maximize their autonomy because they have more to lose by increasing their dependence upon their husbands (1988). In translating this cultural norm to negotiations of labor supply, Kandiyoti argues that women in subSaharan Africa are generally able to negotiate the allocation of their labor in such a way as to increase the income earning activities for themselves while minimizing unpaid domestic labor (1988). Conversely, women in the Middle East and Southeast Asia live in what Kandiyoti terms classic patriarchy, which is characterized by patrilocally extended households with the senior man having authority over the entire household. Women in classic patriarchal societies tend to withstand economic hardship in order to maintain the social system that ensures that they will be protected by their husbands and his family and provided for in old age by their sons. Kandiyoti interpreted this to mean that women are aligning their interest with a system that 
oppresses them (Kandiyoti 1988). This relatively simplistic conclusion does not capture the reality that women's identities are constantly mediated through all aspects of their social location. While in Kandiyoti's analysis, gender plays a key role in understanding women's strategies for survival, women also have membership in class, race, and ethnic groups and the interests of any one of these identities might come into conflict with the interests of another aspect of a woman's identity.

Kandiyoti later revised her interpretation in recognition of inherent difficulties in theorizing about power relations since they are embedded in a gendered hierarchy that has components of race, ethnicity, and class, as well as a complicated emotional and material matrix (1998). In this revision she argues that instead of creating frameworks that cannot take into account the complexities of the situation that they attempt to model, it is necessary instead to examine the underlying assumptions about subjectivity and consciousness that have yet to be analyzed (1998). She encourages the transition away from a conceptualization of patriarchy as a defining framework for understanding household bargaining and instead suggests that by looking at gender, specifically as a relatively disadvantaged social category which reproduces inequalities at every institutional level, a more productive approach can be taken to understand the factors that lead to women's empowerment without being concerned with the content of that empowerment (1998).

Kandiyoti has stepped back from her earlier structural interpretation of gender inequality. Instead of allowing for social structures to constrain choice, she has assigned subjectivity to the perception of choice that, while initially supportive of 
Sen's Cooperative Conflict model of household bargaining, fails to consider the constraints that structures impose on the kinds of choices that women have. Sen avoids this problem by acknowledging that cultural constructs have a real effect on what choices individuals have, but unlike Kandiyoti, Sen does not assume that an individual's perceptions of these constructs are strictly subjective; rather he maintains that there are objective obstacles to the freedom of individuals to choose and, through collective action, these obstacles can be overcome.

This conception of collective action is the cornerstone of Folbre's interpretation of how the constraints that structures impose can affect the choices of women. Because individual preferences are influenced by what groups an individual belongs to and what their position within different groups is, memberships in turn can be contradictory in terms of personal preferences (Folbre 1994). Folbre argues that individuals are conflicted in acting in their best interest because at any single point in time the interests of one group may come into conflict with the interests of another group that the individual identifies with. Membership in these groups is accompanied by sets of norms and assets, which govern the preference ordering for that group, but because individuals have multiple identities these preferences come into conflict.

Folbre views a dialectical exchange occurring between agency and structure, which is in turn mirrored in the dialectic between coordination and conflict. It is in the unfolding synthesis that she situates the family, which is a "set of gendered identities and interest that has both shaped and been shaped by processes unfolding in the market and the state" (1994:39). In terms of patriarchy, Folbre suggests that it should 
be understood in terms of a combination of structures of constraint based on gender, age, and sexual preference (1994:59). Capitalism, on the other hand, should be understood in terms of a combination of structures of constraint based on nation, race, and class (1994:60). These conceptualizations allow for an analytic understanding of how identification with one group is accompanied by a set of constraints that determine to some extent the range of choices available.

The focus on structural constraints determining the bargaining position of women within households was furthered by McElroy and Horney who argue that bargaining power is a function of "extra-environmental parameters" which includes factors such as an individual's non-wage income, the legal structures governing divorce and marriage, the sex ratio in the marriage market, and measures for supporting institutions such as religion (1990). These external factors determine the choices a woman has both in terms of her fall back position and in her ability to work outside the home because they reflect her class, ethnic, and racial membership explicitly while assuming a gender, age, and sexual preference. For instance, in considering an individual's non-wage income what is really being considered is independent wealth and natal familial support, which is reflective of a particular class.

Agarwal argues that there is an intersection between the household and the community, the market, and the state (1997). External support structures have an effect on women's bargaining position within the household, but they also affect the bargaining position of women in these other spheres. For instance, women's property rights affect their bargaining power in the household, but these rights also affect their 
bargaining position in the community and with the state (Agarwal 1997, Deere and Leon 2001). The mechanisms by which ownership of property strengthens a woman's bargaining position include improved income and the ability to produce food (Agarwal 1997). In addition, it has been found to help women negotiate "less restrictive norms and better treatment from husbands" (Agarwal 1997). The right to own property and to contest unfair inheritance also depends on legal and governmental institutions.

Especially at the local level, support for the rights of women to own property is crucial if a woman needs to press for those rights to be recognized (Agarwal 1997).

Additionally, whether a woman has the educational capacity to represent her interests in an effective way has an impact on her bargaining position (Agarwal 1997, Deer and Leon 2001). Agarwal includes eight factors that affect bargaining position in these different contexts which include, in addition to women's property rights, women's access to employment and other income-earning means, the household's class or caste position, access to village commons, support from kin and friends, support from gender-progressive NGO's, state support, and social norms and perceptions (1997).

While these theoretical perspectives help to understand the different dimensions of female agency and empowerment, when applied to studies of immigrant women they fall short of providing the necessary tools that are required to settle the contradictory identities that immigrant women embody. Earlier the concept of mediated social location was introduced as an extension of Wright's concept of mediated class location (1997). Immigrant women occupy a space that is located between two different structural systems, meaning that the formation of their identity 
is constantly being mediated by the norms and values of their country of origin, which are reasserted through social networks, and the norms and values of their destination. While it would be ideal if women could pick and chose the most enabling of these identities, there are historical reasons to suspect that the influences of patriarchy and capitalism work to constrain women and limit their choice.

\section{Previous Studies}

Over the past fifty years women have entered the paid labor market in growing numbers. Since the 1980's the migration of women in search of work has increased (Gamburd 2000). The expectation of many scholars has been that this growing migration of women workers will result in a shift in household roles and a restructuring of power within households (Hondagneu-Sotelo 1999, Gamburd 2000). In the following short section, various studies are presented that have examined how migration and paid work affect household dynamic. Instead of unequivocally increasing the power and decision-making ability of women wage earners, the research suggests that women's class, race, gender and ethnicity play key roles in determining the effect that migration and employment will have on her bargaining position. The following studies illustrate that the class location of an immigrant household and the type of employment that women engage in has an impact on her bargaining position within the household. The cultural ideals about gender and household relations that were held in the country of origin are also shown to have an impact on a woman's bargaining position. These ideals influence the amount of control women will have over household resources at the point of destination. 
One study that illustrates the importance of contextualizing gender relations in the destination country within the historical attitudes toward gender in the country of origin was a study that examined two populations of households that had immigrated to California from Central America. This study found that indigenous men, who came from relatively egalitarian backgrounds, welcomed their wives' financial contributions to the household while men from non-indigenous backgrounds and who came from less egalitarian backgrounds felt threatened, especially in cases when their wives' earnings exceeded their own (Menjívar 1999). This study also highlighted the importance of labor market location in understanding how cultural changes are negotiated in households. For instance, among non-indigenous households, women were often employed as domestics in middle class American homes where they would observe husbands and wives sharing in household labor and child rearing. The researcher suggests that this exposure helped to provide a basis for these women to raise issues regarding household division of labor with their husbands (Menjívar 1999). The husbands, meanwhile, found employment in a context that put them in close contact with other Latino men, which reinforced a way of life that placed them in control of the household (Menjivar 1999).

Another study examined the intersection between community, the household, and the labor market and compared two populations of Bangladeshi garment workers, one group in the United Kingdom and the other group in Dhaka, Bangladesh (Kabeer 2000). The researcher found that a negotiation occurs within households when women attempt to enter the labor market and that this negotiation is contextualized in an 
interwoven fabric of socially determined expectations of gender roles, desires to maintain the rights and responsibilities of those roles both within the household and outside of it, and a competing desire for the economic gains associated with labor market participation (Kabeer 2000). Women who are perceived as challenging these norms by asserting a desire to work outside of the household encounter a range of resistance both in the community and within the family that ranges from resigned acceptance to brutal abuse (Kabeer 2000). This intersection of motivations and expectations has different outcomes that depend on a variety of factors including whether the male head of household perceives that he will be able to maintain the patriarchal privileges associated with his socially determined status and whether an increase in household income is worth the threat to his position (Kabeer 2000). Women, in addition to negotiating their intentions to seek employment within their household, had to overcome community resistance that was influenced by religious leaders as well as social norms that discouraged women from being seen (Kabeer 2000). The researcher also found that women had to overcome their own perception that leaving the protective walls of the home to seek employment was morally and socially acceptable (2000).

Yet working outside of the home in both the formal and informal paid labor market is just one dimension of the work that women do in society. For many women in the developing world and particularly for the women involved in the study, the decision to enter the paid labor force was considered only after a determination of whether they could continue to fulfill their responsibilities as wives and mothers 
(Kabeer 2000). In terms of this unpaid domestic work, women reported either doing it on days off, allocating it to other women in the household, and even in some cases hiring it out to other women (Kabeer 2000). The tendency for women to take responsibility for this work went uncontested and their ability to fulfill this responsibility was found to be the primary determinant of whether women would consider participating in the paid labor market (Kabeer 2000).

Donnelly (1994) conducted an ethnographic study of Hmong refugees who resettled in Seattle, Washington in the early 1980's. These refugees, transferred as a group, were able to re-create much of their cultural context in their new home, but at times had to adapt to the structures of the United States. An example of this adaptation proves valuable in demonstrating the impact that structures have on the survival strategies that immigrants employ, but these strategies do not necessarily transform the gendered relationships within the household. For example, in response to economic need, Hmong women began producing elaborate needlework and other craft items, which in their culture were given as gifts but in Seattle were sold in markets. The profits from this endeavor, rather than increasing the control that women could assert over household financial decisions were instead placed in the traditional realm of male authority (1994).

Another study that examined Korean immigrants in New York City found that women who worked with their husbands in an entrepreneurial endeavor not only lack control over earnings, but the work that they do in the business is typically unpaid, and often considered to be an extension of the household labor that they are also expected 
to do (Min 1998). The social norms of the ethnic community further impaired Korean wives' opportunities for agency by enforcing the expectation that a woman's work was not to be valued beyond the benefit it brought to her husband. Even when the wife played a dominant role in managing the business, the husband was still considered the owner by the extended family and by the Korean community (Min 1998). While the social network that had evolved in this Korean community helped to ensure higher household earnings, these earnings disproportionately benefit males at the expense of females. The researcher also found that, compared to other Korean women he studied, those employed in this type of scenario lacked access to networks of support, namely the female networks of support that other women cultivated when they were removed from the conditions of patriarchal supervision.

Finally, a study that explores the survival strategies of Chinese immigrants who came to Queens, New York in the early 1980's emphasizes the role of gender and class in determining the immigration experience. The researcher's focus in this study is broad - he examines the reasons that immigrants migrated to Queens, the social networks that have evolved that help them find employment, housing, and financial support, how housework is divided along gender and generational lines, communities that individuals join for additional emotional support, and the relationships between immigrants and those who are still in China (Chen 1992).

The researcher divided his participants into three classes, the working class, the small business class, and the professional class. Among the working class he found that women "in this class have shown a strength and ability to work and survive even 
without their husband's assistance" (Chen 1992:103). Working class immigrants survived by working in ethnic enclaves in jobs that they found by reading Chinese language advertisements. Of the case studies that are presented, the case of a woman who migrated with her two daughters as a way of leaving an abusive relationship in China demonstrated the importance of gendered networks in obtaining employment. In search of work that would allow her to care for her daughters, this respondent struggled with finding housing that was close to her job, and with finding work that could be done from home during what was, in reality, her third shift of the day, the other two being a caretaker for her children and her night job at a local factory (Chen 1992).

The ethnographies of the small business owning class of Taiwanese immigrants shows households structured around partnerships where husbands and wives engage in running a business together with other women being hired to care for their children and their home. The money to open the businesses comes from a variety of sources, but most often is saved while in Taiwan or while working in the United States. Occasionally the money comes from a pooled loan from community members or "credit club." Although gender is part of the analysis, what was most striking was the dependence on social rietworks to compile the capital needed to expand a business or to move from owning a small convenience store to operating a large grocery. While there is some evidence that some of these networks were available to women, in many of the cases women left the decision to expand a business to their husbands (Chen 1992). There was also evidence that a wife's family would place demands upon her, 
especially in terms of helping a family member migrate and find work, which were outside of her ability to address. In turn, women had to convince their husbands to take on this additional responsibility (Chen 1992).

Among the professional class, the amount of time spent working is much less than among the other classes and lifestyles, allowing them to include time for vacations and for spending time as a family. Women work in jobs but little was said of how this employment affected their role within the household. What was remarkable among the professional class was the amount of time they tended to invest in community organizations that were designed to promote the well being of the working class Chinese (Chen 1992).

\section{Conclusion}

This review of the literature emphasizes the need to take a gendered approach to understanding immigration and its consequences. Women have emerged on the forefront of the global economy. Women are migrating in increasing numbers as a strategy to secure the economic resources to support their families and when they arrive at destinations, they create their own families that need their support. It is within this nexus of households, both local and transnational, where women are theorized to be re-negotiating the contracts they have with both families. How a woman strategizes to meet the needs of her household in the country of origin depends in a large part on how her strategies and negotiations within the constraints of the household at the destination. The literature that has been reviewed suggests that there are macro forces that help determine women's bargaining position within households, but that there are 
also micro forces such as the perception of those involved in the negotiation of what each member contributes to the household. Women's work inside the house has long gone undervalued. Women's work in the labor market has also gone undervalued. The question then remains, from this position, how do women from immigrant households whose status has shifted relative to men, experience this shift? 


\section{Chapter III \\ METHODOLOGY}

\section{An Exploratory Study}

This research project is situated at the intersection of migration, gender, and labor and is contextualized within households. The specific aim of this research is to explore how immigrant women from Ethiopia and Eritrea share a subjective account of the experience of migration and employment and if and how these experiences contribute to women's agency in household negotiations. Because this research seeks to explore how women construct a narrative of their experiences, this research utilized depth interviews as a data collection strategy. Depth interviews involve the development of a relationship between the researcher and the study participant that is based on a discourse that is directed towards gaining a mutual understanding of an experience. It acknowledges the social location of the interviewer and of the participant. Because the interviewer in this research does not share a cultural identity with the study's participants, this data collection method was chosen with the expectation that it would help bridge a cultural divide.

The primary research question that guided this project is how the relocation experience and subsequent employment has affected hous shold negotiations. Migration is examined from a gendered perspective and is viewed as a household response to a both a global economy that has put increasing pressure on women to ensure household survival and an ongoing civil war that has destabilized both countries. Entrance into the labor market is also examined, specifically from the 
perspective of how women describe that experience, how this experience affects their ability to make decisions, and how working affects women's household responsibility, both locally and at the country of origin.

\section{Sample Characteristics}

The aim of this research was to begin theorizing about the dynamics of shifting power relations in immigrant households. To achieve this, it was necessary to gain a deep understanding of the complex relationship between migration and employment and the effect that these two relatively concrete experiences have on household negotiations, specifically the dynamics of power within a household. For this reason, a small sample of women was selected and depth interviews were conducted that were designed to elicit narrative histories, which were determined to provide the greatest level of depth and understanding for the researcher.

Nine women were purposively sampled from the population of Ethiopians and Eritreans living in Portland, Oregon for this study. The average age of the informant was 38 , with a range from 19 to about 50 years old. The informants had lived in the United States on average for 16 years, with one woman here for only 4 years and two having lived here for 32 years. Two of the women immigrated as refugees, one as an asylum seeker, two had come in with student visas and then applied for resident status, and four entered the country as immigrants. With respect to ethnic diversity, of the women who are included in this sample, two women are from Eritrea and seven are from Ethiopia. Of the women from Ethiopia, three openly identified as Oromo and two identified themselves as Amharic. Two others did not identify their ethnicity (table 2). 
The class location of the participants in this study is mediated by the experiences of migration and employment. Traditional class analysis in sociology identifies an individual's class location in relation to their economically relevant assets or resources (Wright 1997). This often is interpreted to mean that the occupational status of a person's parents and the educational attainment of an individual are good indicators of a person's future class status. In this case, this would suggest that the class location of the participants in this study range from working class in the case of the truck driver to upper class, in the case of the women whose parents are an executive and a doctor.

Table 1: Sample Characteristics

\begin{tabular}{|l|l|l|l|l|l|l|}
\hline Informant & Age & $\begin{array}{l}\text { Current } \\
\text { occupation }\end{array}$ & $\begin{array}{l}\text { Years } \\
\text { in US }\end{array}$ & $\begin{array}{l}\text { Father's } \\
\text { Occupation }\end{array}$ & $\begin{array}{l}\text { Mother's } \\
\text { Occupation }\end{array}$ & $\begin{array}{l}\text { Immigrati } \\
\text { on Status }\end{array}$ \\
\hline $\begin{array}{l}\text { Ethiopian } \\
\text { Amharic }\end{array}$ & 26 & $\begin{array}{l}\text { Student (bank } \\
\text { administration) }\end{array}$ & 8 & Construction & Home & Immigrant \\
\hline $\begin{array}{l}\text { Ethiopian } \\
\text { Amharic }\end{array}$ & 35 & Store clerk & 17 & Judge & Home & Asylum \\
\hline $\begin{array}{l}\text { Ethiopian } \\
\text { Oromo (*) }\end{array}$ & 19 & $\begin{array}{l}\text { Student } \\
\text { (Hotel } \\
\text { housekeeping) }\end{array}$ & 4 & Oil industry & Secretary & Immigrant \\
\hline $\begin{array}{l}\text { Ethiopian } \\
\text { Oromo }\end{array}$ & 30 & $\begin{array}{l}\text { Health Care } \\
\text { worker }\end{array}$ & 10 & Truck Driver & Home & Immigrant \\
\hline $\begin{array}{l}\text { Ethiopian } \\
\text { Oromo }\end{array}$ & 50 & $\begin{array}{l}\text { Restaurant } \\
\text { Owner }\end{array}$ & 32 & Minister & Home & $\begin{array}{l}\text { Student } \\
\text { Visa }\end{array}$ \\
\hline $\begin{array}{l}\text { Ethiopian } \\
45\end{array}$ & $\begin{array}{l}\text { Restaurant } \\
\text { Owner/ Student }\end{array}$ & 10 & Business & Home & $\begin{array}{l}\text { Student } \\
\text { Visa }\end{array}$ \\
\hline Ethiopian & 35 & $\begin{array}{l}\text { Restaurant } \\
\text { Owner }\end{array}$ & 17 & Business & Home & Refugee \\
\hline Fritrean 1 & 50 & $\begin{array}{l}\text { Community } \\
\text { worker }\end{array}$ & 32 & Executive & Doctor & Immigrant \\
\hline $\begin{array}{l}\text { Eritrean } \\
2\end{array}$ & 40 & $\begin{array}{l}\text { Health care Aid, } \\
\text { Worked in } \\
\text { husband's store }\end{array}$ & 16 & & $\begin{array}{l}\text { Home } \\
\text { (divorced) }\end{array}$ & Refugee \\
\hline
\end{tabular}

* In this case, the daughter of a recent immigrant was interviewed who answered questions that reflected her mother's experience

A problem with this approach is that class location does not always translate across cultures, especially when the resources acquired in one location do not maintain their 
value when they are taken out of context. For this reason, and because the type of jobs that the study participants and their husbands engaged in, the mediated class location of most of the participants can be considered to be working class. The exception was one woman, the Eritrean Community Worker (table 2), who managed through marriage and the subsequent migration of her parents to Canada, to maintain and possibly even improve her class location.

A more complicated problem arises when one tries to identify the mediated social location of the study participants. Historically, the subjugation of women has resulted in gender being the primary determinant of a woman's class (Wright 1997). From a Marxist perspective, woman's historical relationship to the means of production has placed them in the proletariat; a woman can never own the means of production, particularly when she is considered a commodity herself. Freed from this position by a growing demand for women's labor, women have entered the labor market and are defining their own class location, while at the same time transforming the meaning of gender. Social location is not an independent variable in the same way class location can be. It shares with class location the concept of consciousness and its relationship to the structures in a society. Marxists argue that there is a set of attitudes and identities that accompany a class location, for instance, the macho attitude that might be found in a manufacturing plant (Wright 1997). Likewise, there is a set of attitudes and identities that accompany social location. The set of attitudes and identities which women in this study had regarding gender in particular, but also race 
and ethnicity, while growing up in Ethiopia and Eritrea were revised after migration.

This mediated social location is explored fully in the following chapter.

\section{Data Collection: Depth Interviews}

The success of this research project hinged on the ability of the researcher to gain entry to a relatively narrow population of people, navigate within a system of cultural norms that was different from her own, and develop a level of intimacy that would make it possible to ask questions about a private area in peoples' lives. In order to achieve this it was necessary to convince participants to enter a partnership where an understanding of their life story was constructed through a conversational discourse. Depth interviewing is a "constructed dialogue focused on a creative search for mutual personal understanding of a research topic" and was selected as a method of gathering data (Miller and Crabtree 2004:196). Depth interviews rely on the researcher's ability to reflect on what the informant says and how the informant communicates in order to "learn how to ask" (Miller and Crabtree 2004). In other words, this method requires an inductive approach to the research question where emergent themes and concepts are used to formulate new interview questions.

The data gathering method for this research was selected also because it provided a way of acknowledging the role of the interviewer, not as a passive recorder of an event, but as an active participant in the development of an understanding of the meaning of an event. This method is designed to obtain a narrative and relies on the interviewer and informant to engage in a purposeful discourse directed toward the construction of mutual understanding regarding the cultural meaning of an event. 


\section{The Research Process}

As mentioned in the introduction, there is a substantial Ethiopian and Eritrean community in Portland, but the researcher was not a member of this community so the first task was to find out more about the community. In order to gain entry to this community, Ethiopian and Eritrean community leaders and business owners were identified through an extensive search of the local newspaper, The Oregonian. All of the articles from a five-year period that mentioned Ethiopians or Eritreans in the Portland area were compiled. A list was then made of all people mentioned who were either community leaders or business owners and efforts were made to find contact information for these individuals.

These initial contacts were asked to share information about the Ethiopian and Eritrean community, specifically about the size and composition of the community and about ethnic organizations including churches, mosques and community centers in the Portland area. Conversations with contacts were informal, with notes taken immediately afterwards.

Once the general parameters of the Ethiopian and Eritrean population in Portland were gauged, a sampling design was constructed that emphasized strategies of including the broadest possible range of women in terms of class, ethnicity, and length of time in the United States. This purposive sampling technique meant that, rather than relying on one individual's social network as a way of identifying potential informants, potential informants were identified through several different contacts. These contacts included several different business owners and community leaders, 
English as a Second Language programs at community colleges, and non-profit organizations that assist in settling immigrants and refugees. This strategy was designed to maximize the richness of the data collected by creating a broad population of Ethiopian and Eritrean women to select from.

The interviews were organized around an interview guide that consisted of several closed-ended questions to identify informants and gain biographical information, and a few open-ended questions with associated prompts and follow-up questions intended to elicit a "big picture" response. The initial questions were rapport building and were intended to build trust and to act as a bridge to intimacy (Miller and Crabtree 2004). These were followed by the introduction of research themed questions designed to elicit narrative responses that were rich in detail.

The biographical questions lasted ten to fifteen minutes and included questions about where the informant grew up, who lived in their household, their father and mother's occupation, the number of siblings, and educational experiences. These questions provided information for subsequent narrative building questions.

The big picture questions were open-ended and chronological. Informants were asked to share the story of their migration and employment experiences. This usually elicited a narrative history up until the present time, after which informants were asked about household relations. This was the most sensitive question broached in the interviews and it was necessary to gauge the informant's comfort level in determining how to ask this question. Some informants were very comfortable discussing household gender relations while others required a more subtle approach. For instance, 
one effective strategy was to ask about the household in a very general way and then follow up with a depth probe that would usually involve a hypothetical question or a fictional scenario. This de-personalization of the topic would often open up the conversation.

The interviews took place in people's place of employment, in the case of restaurant owners and shopkeepers, and in public places such as coffee shops and at local colleges. In an effort to ensure that the informants felt comfortable during the interviews, they were encouraged to select the location. Efforts were made to avoid conducting interviews in what has been referred to as a "white room" or a sterile environment, which could have a dampening effect on the richness of narrative detail (Miller and Crabtree 2004:194).

Initial contact with the informant was made either in person or over the telephone. This contact provided an opportunity to introduce the general goals of the research project, and assure anonymity (Miller and Crabtree 2004). A time and place for the interview would then be scheduled, usually within two or three days. At the time of the interview, the informed consent form was reviewed (Appendix A), emphasizing the voluntary nature of their participation, the ways the informant's identity would be protected, and note taking and recording methods were discussed. The informed consent form included a separate consent for recording the interview with a voice recorder.

Miller and Crabtree explain in their overview of depth interviewing that it is particularly important that the interviewer learn his or her part. They suggest that the 
interviewer should spend time learning as much as possible about the informant, and that the interviewer should spend time in the informant's neighborhood, getting to know their environment (2004). In order to gain knowledge of the informants, a historical account of Ethiopia and Eritrea was read, and an on-line search was conducted of local businesses. Time was also spent in the neighborhood where there is the highest concentration of Ethiopian and Eritrean owned businesses. These efforts helped develop cultural sensitivity to the different ethnic groups that were encountered over the course of this research and helped gain an understanding of the difficult circumstances that women who migrated had left behind. All but one woman in this sample migrated without their extended family, leaving family members in a violent environment. This was often a point of great sadness and emotion, and it was important that the interviewer acknowledged this. By showing sympathy, women became more comfortable sharing aspects of their narrative that would otherwise have gone unexplored.

Refining the method of data collection was not a linear process, and in retrospect the first interview shows a lack of understanding of the day-to-day lives of the informants. It was through the process of transcription and reflection that the undercurrents of this lack of understanding in the initial interview emerged. For example, during the first interview, in response to a question about her family in Ethiopia, the respondent replied in a way that showed that she did not think that the interviewer understood what was being asked with respect to her family in Ethiopia. She said: "It is very different in the third world. Have you ever been to the third 
world?" This indicated the importance of demonstrating a basic cultural understanding to informants by framing questions in a more contextualized manner. In subsequent interviews an effort was made to incorporate both intellectual knowledge of third world societies and first hand experience of living in a third world county when asking women to share their experiences and reflect on the current conditions that their extended family members are facing in Ethiopia and Eritrea.

The interview guide evolved throughout this reflective process. Although it was always organized to gain a big picture perspective of the lives of the women in the study and to contextualize the relocation experience within the broader framework of family and community, the way of asking questions was continuously adjusted after gauging what kind of information the respondent was volunteering to provide. All interviews focused on encouraging women to share their experience of working in the United States and the household dynamics around household management activities. The interview concluded with questions that were intended to have respondents reflect on the relocation experience.

At the end of the interview, notes were put away, the recorder was turned off, and informants were thanked for their time. Women were invited to ask questions about the interview, or about the research. During these short informal periods new information would occasionally emerge. For instance, one woman revealed that she really wanted to move closer to her sisters and brothers but her husband refused and that this was a point of contention. 
A subset of women were invited and agreed to participate in follow-up interviews that were far less formal and often involved getting together to share food, go for a walk, or have a cup of tea. In all but one of these cases, this subset of women were selected based on a reciprocal agreement that the researcher would assist them by advising them on strategies they could use to improve their chances of gaining admittance to an academic program. Other researchers have acknowledged that a reciprocal relationship is appropriate when gaining access to a population (Lofland and Lofland 1995:59). The exception was one informant who was enthusiastic and willing to be helpful and freely made herself available for follow up questions. These informal interviews provided an opportunity for participants to provide more detail regarding specific household negotiations and created an opportunity to introduce themes that had emerged after the initial interview had been conducted, or to reintroduce topics that had gone unexplored during the initial interview.

During the first wave of interviews, memos were taken to both help refer back to events during the interview and as reminders of things that were emphasized. At the conclusion of each of these interviews, the recordings were transcribed and notes were made to capture the physical information that was not apparent in the language of the interview. This included things like the informant crying or otherwise expressing emotion. On some occasions the opportunity to observe the informants interact with their husbands was presented and the information that was gained from watching these interactions helped to contextualize household relationships, often confirming the supportive nature of these relationships. 
The transcribed interviews were read multiple times in order to gain familiarity and to focus on emergent themes. Upon each reading, a different perspective was gained. Reflecting upon this, the interviews taken as a whole offer a different picture of experiences of immigrant women than any one interview can provide. Finding points of similarity helped reveal nuances in the narratives and issues that were sometimes underemphasized in one interview would emerge as an important theme in another. This process of transcription and reflection helped to focus the interview questions and probes in a more narrow way as the interviews proceeded. This helped inspire confidence and trust among the informants, while providing richer narrative material and a deeper understanding of the experiences that were conveyed.

Guided by the theoretical concepts that were developed in the literature review, transcripts were examined for evidence of these concepts. These concepts were tagged and color-coded to assist in the identification of emergent themes across the various transcripts.

In asking women to provide a narrative of their experiences, an inductive approach to the research questions was adopted with the hope that in the telling of their story there would be emergent themes and concepts that would explain household gender dynamics. What respondents chose to share helped to determine which interview questions would be asked. What became apparent over the course of conducting several interviews was a discussion of remittances sent to the country of origin, which was not in the original conception of this research project. The way women negotiated in households and framed their employment as a way of securing 
these remittances emerged as a key concept in understanding the negotiation of household financial resources.

After several interviews were conducted, the reiterative process that is the central feature of depth interviewing began to plateau. While in the beginning the interview guide had to be revised several times, during the final interview little new information emerged. The data that could be collected was nearing exhaustion and there was the sense that a protective wall had been encountered. One particularly frank informant confirmed this during a follow-up interview. She indicated that there were areas where Ethiopians and Eritreans would not be comfortable exploring. This primarily had to do with the topics that triggered household disagreement. Because these topics are by their very nature private, it was determined that the absence of information on the particular subjects that provoked strong discussions did not jeopardize or adversely affect the core of this research project. Feeling that adequate data had been gathered and wishing not to compromise relationships with informants by pushing the interviews beyond the point where they were comfortable, the study was concluded. 


\section{Chapter IV}

\section{FINDINGS}

In the introductory chapter, three research questions were introduced: the first question asked who immigrant women were supporting through their labor; the second question asked how immigrant women found employment and what strategies women used once employed to meet the competing demands of household responsibilities and employment; and the third question asked to what extent women felt that they were able to maintain control over their income and influence household decisions. Women in this study responded to these questions in a variety of ways, but throughout the data gathering and analysis process, common themes emerged that suggests their experiences share some common traits. In the following, each research question is taken in turn and the emergent themes are discussed and illustrated with quotations from the interviews.

\section{Migration, Remittances, and Natal Household Relations}

War and political instability were a constant presence in the narratives that women shared. They exacerbated the effects of globalization, led to a decline in economic opportunities and challenged the ability of households to secure resources. Many women indicated that the decision 0 emigrate was made because of long-term political instability in Ethiopia and an ongoing war and conflict between Ethiopia and Eritrea. The war between Ethiopia and Eritrea displaced families, forcing them to move across borders in order to align their national identity with their geographical position and to avoid violence. One respondent tells of having to move from Axum, 
Ethiopia to Eritrea to escape violence, only to find that the violence had followed them, forcing them to move again to Addis Ababa, the capital city in Ethiopia. Upon finishing high school, this woman was sent to the Untied States by her father to live with her older siblings who were already here. Another respondent tells of having come to the United States on a student visa and repeatedly extending the visa to avoid returning to an unstable Ethiopia after a leader was violently overthrown. This decision was made again after the new Communist led government proceeded to nationalize industries, banking, and rural land. Eventually, after marrying and starting a family, the woman and her husband decided to remain in the United States permanently.

The class location of households was deeply affected by the ongoing conflict since it threatened the stability of societies on both sides of the border. Leading up to the on-going war between Ethiopia and Eritrea, Ethiopia was beset with multiple coups and a take-over by a Communist government, which nationalized many resources and firms, directly threatening the security of many wealthy Ethiopian households. Many informants reported that their families, particularly their fathers, wanted to send their children to the United States because it was believed that there would be mor 2 educational and employment opportunities. This suggests that migration was used as a strategy for maintaining the class location of a household, since implicit in the decision to send a family member abroad was the expectation that remittances would be forthcoming at a time when households had limited opportunities because of the war. The decision to send sons, as opposed to daughters, 
was not a clear trend, with many women reporting that they were given similar encouragement to migrate to the United States as their brothers.

When household resources allowed for it, children were sent to the United States for college, although this was prohibitively expensive for all but the wealthiest Ethiopian and Eritreans. More often women in this study reported that they were sent to the United States with the expectation that they would work, become proficient in English, and attend school at a community college at their own expense. Among the women who came from affluent households, families appeared to emphasize education equally for males and females. Among those who came from less affluent households, many women reported that families, particularly mothers, stressed the importance of education, especially for girls. One woman, whose mother could not read or write, was adamant that her daughters have the same educational opportunities as her sons and would reiterate her regrets that she had not learned to read.

In the majority of the cases that are considered in this study, the decision regarding which household member should migrate was not limited to one member, but instead multiple members of a household migrated, and frequently to the same geographical location as another sibling. There is a class component to this trend; women whose family's class location was working class were more likely to report that the decision to emigrate was made after the woman had married. In two of these cases, the woman's husband was identified as the one who made the decision, and in the other case the woman had been an advocate for immigrating to the United States because she wanted her children to have greater educational opportunities. 
In terms of gender, the only reported difference in the trend of sending all the siblings in a household to the United States among the respondents in this study who were not married when they emigrated was a tendency, in households where there were 8 or more children, for one daughter to remain in Ethiopia to help care for aging parents. In households with fewer children, all of the children in the household emigrated.

Among women in this study who emigrated after marrying, there was not the same tendency for all of the siblings to emigrate. This suggests that migration became a strategy that the newly formed household used to improve their social location and that the natal household was not affecting the decision to emigrate in the same capacity that it affected the decision to emigrate among the women in this study who emigrated before marrying. This difference is reflected in how much support that women felt compelled to give to their natal households in the form of remittances.

The households that depend upon remittances for survival consist of parents and remaining siblings, but can often include aunts, uncles, and people in the community who do not have other means of support. Women who migrated before marrying reported that they felt compelled to send money, not just to their parents, but also to extended kin and community members. One woman who spoke extensively about the importance of sending money to her family said: "It is hard for old people, like my Mom and Dad. They do not work anymore so they need help...There are six of us [herself and her siblings] and the youngest two are in school, they do not send any money. So we always send $\$ 400$, every month for our family, to take care of them." In 
addition, this woman explained that she and some co-workers would contribute money from their paychecks to send to households in Ethiopia that her parents had identified as being in need: "We were helping them [two families] for three years, every three months we sent them money and they didn't know who sent them the money because we did not know how long it could continue. My mom told them that there were people in America who wanted to help and that her children told them to help these people." In contrast, women who emigrated after marrying still reported that they sent money to their natal families, especially around holidays, but they did not report feeling similar levels of responsibility in supporting their natal family, or extended kin and community members.

Other factors that affected the amount of responsibility women felt for supporting their natal family was the amount of time that they had lived and worked in the United States. Regardless of whether they had migrated before or after marrying, women who have lived in the United States for more than 10 years indicated that they had slowed the flow of remittances as part of a strategy to secure their own class location in the United States. For instance, one woman who had lived in the United States for over ten years and had migrated before marriage had stopped sending regular remittances to her natal family and instead only sent money on holidays. She was using the money that she would have sent to pay for her college education.

This research takes as its starting point that social, political, and economic structures, particularly globalization and conflict, are changing the constraints that define women's opportunities. The argument has been made elsewhere in this paper 
that globalization is increasing the demand for female labor and that households are increasingly depending on women's wages as a survival mechanism. With respect to natal households located in the developing world, particularly in a region that has been beset with long-term political instability, women's participation in the labor market has become an important source of household support. This strategy is particularly useful when natal households are able to send daughters to the United States, since there is a tendency for these daughters to feel a great deal of responsibility towards maintaining the class location of their families as well as helping to supported extended kin and community members. The ability to send a daughter to the United State reflects a level of affluence, though, and does not appear to be a strategy that all Ethiopian and Eritrean households can use.

Because this study did not include the amount of support that male children remit to their natal households, it is not possible to conclude whether natal households are better off supporting the emigration of sons as opposed to daughters. What was clear from the interviews was that the greater the number of siblings that had migrated, the less pressure women in this study felt to support their natal families. In cases where many siblings had migrated, siblings would organize their remittances to ensure that the natal household had the money that it needed, and that the each of the siblings' households were contributing according to their relative ability. In contrast, one woman, reflecting on her early immigration experience, reported that she worked multiple jobs and lived in a shared apartment to reduce her own costs so that she could support her parents and all of her siblings that were still residing in Ethiopia. She 
reported that she was under immense pressure to direct as much as she could to her natal family who were suffering hardship because of the political instability: "My family was not doing well. My father was in jail and my mother had nothing. I worked so I could send them money, clothes, shoes, anything." Once her siblings were able to migrate, this pressure lessened and she was able to direct her earnings towards improving her own class location.

\section{Employment and Social Networks}

As the Ethiopian and Eritrean immigrant population in Portland has grown over the course of the past fifteen years, the range of jobs available to women has diversified. Women who moved to Portland more than ten years ago reported that jobs were difficult to find when they arrived, but that today there were far more opportunities. The theories regarding social networks and employment that were presented in the literature review suggest that part of this change is a result of improved social networks that have evolved to become more effective at informing immigrants of employment opportunities and providing information regarding how to obtain the skills that are necessary for securing employment. Another reason that has been suggested for this change is that globalization has increased the demand for female employment in the service sector.

As social networks in the Portland metropolitan region have developed, women in this study conveyed employment histories that reflected a broadening array of employment opportunities and a tendency for women to find jobs in the service sector. As noted in the sample characteristics (Table 2), all but one woman in the study 
worked in the service sector, and the one woman who was not employed in the service sector was unemployed and looking for work in her occupational field after moving from Oakland, California. She had worked as a bank administrator and was having a difficult time finding a similar position in Portland. When asked if she spoke with other Ethiopians in the community about job opportunities, she said that she had, but that "most [Ethiopians] in Portland, worked at parking places and senior assisted living places, and gas stations," as opposed to her experience in Oakland where the employment opportunities were more cosmopolitan and paid a higher wage. As a result, she did not think that accessing the social networks would benefit her in her job search.

Other women utilized social networks in identifying job opportunities, although women were just as likely to find jobs either on their own, or to create a job for themselves, as in the case of women who opened restaurants and one woman who became a provider of adult foster care, an opportunity that was made available to her through her husband's relative. The real value of social networks for women in this study emerged as a way of creating a connection to their culture, particularly around holidays, as a way of transferring cultural knowledge to children, and as a resource when employed but struggling to meet the domestic demands of the household. Women described the first two functions of social networks when they were asked to reflect on ways they connect to the broader Ethiopian or Eritrean communities. Women would often refer to events at a church or community center which they would participate in only on holidays or when a native language class was being 
offered for their children. The latter function of social networks is of interest to this study.

Women who migrated more than fifteen years ago tended to start their own business as restaurant owners. Of the three restaurant owners in this study, two started out as small establishments, such as a food cart, before expanding to a permanent location. All three restaurants specialized in preparing Ethiopian food, relying on the skills that they had learned in Ethiopia. Interestingly, in two of the cases, as the businesses expanded and the restaurants gained a level of popularity, the husbands began to work in the restaurants with their wives. Even in the case where the husband did not entirely quit his other job, husbands took on the responsibility for filing papers and ordering supplies, essentially being responsible for the financial aspects of the restaurant, while their wives worked in the kitchen preparing food and serving customers. There was a tendency among restaurant owners for the domestic responsibilities of child care and food preparation to be shifted to the restaurant location, with space set aside in restaurants for children to do school work and nap and women reported that little to no food was prepared in the kitchen of their home. This was illustrated by one woman who described constructing a room in the back of the restaurant for her infant to stay in while she prepared food for the restaurant: "I hired a daughter of a friend and we remodeled the room over there [pointing], behind the kitchen, and she would come after school and watch the girls."

Similar to restaurant workers, women who worked in small markets that catered to the local Ethiopian and Eritrean communities also were able to bring their 
children to work with them, which was an important benefit. One case that illustrates the value of this benefit was a woman who had gone to school and obtained certification to be a dental hygienist. After working in a dental clinic for several years, she quit after having a child, wishing instead to find a job where she could care for her son: "I like it [her job as a grocery clerk] because I can leave if there is a problem and go pick up my son....and he can come in here while I work." Although other women reported that they would coordinate childcare and other domestic responsibilities with other female family members, this woman lacked access to many of these networks as a relative newcomer to Portland and as someone who had deviated from cultural norms by having a child out of wedlock. Perhaps partly as a result, she depended on paid day care for her son during most of her shifts.

Another woman created a job for herself that allowed her to stay home and look after her children by becoming an adult foster care provider. This employment strategy created a way for her to meet the demands of the household while earning money to support her natal family in Ethiopia. This woman became an adult foster home provider after speaking with a male cousin of her husband who had pursued this avenue several years earlier.

In contrast to women who were able to create or find a work environment that helped facilitate their ability to meet their domestic responsibilities, women who worked in locations that were not conducive to bringing children with them to work developed a range of strategies to meet the demands of the household. Women recruited the help of family members when possible, including having their children 
help with household chores to meet their household responsibilities. When young children needed care, women reported that they would tap into social networks, identifying sometimes distant relatives who also needed childcare and moving closer to them so that childcare responsibilities could be shared: "I did not have a babysitter with my kids. See, my brother-in-law moved here from Sudan and we lived in the same apartment. My sister-in-law worked in the evening and I worked in the early morning. So they were all asleep when I went to work, but in the morning, when my husband was gone, my brother-in-law was up so they took my daughter and I could sleep. So when I woke up at two, I got my daughter back and my sister-in-law would go to work." After speaking with other women it became clear that childcare was not the only responsibility that women developed strategies to "cover" in the pursuit of balancing household labor with employment. As is clear from the above quotation, whenever a male member of the household was awake, either the women that was interviewed or her sister-in-law were also awake. This emerged as a strategy which women used to ensure that the other demands of the household were being met, such as food preparation and shopping. This situation was considered a short-term solution and was not the preferred way to fulfilling needs within a household. An alternative solution involved having parents, particularly a woman's mother, come and stay for one to two years after the birth of a child, usually the first born, so that the grandmother could care for the child while the parents worked. Although husbands were seldom recruited to help care for small children, women did report that they 
helped care for school aged children. In addition, several women reported that their husbands helped with food preparation, shopping, and other household tasks.

One area of household labor that emerged in several cases as falling under the domain of males was the responsibility for shopping and errand running. Several women expressed gratitude that their husbands were willing to take on this responsibility and were willing to do the remainder of the housework in exchange for not having to participate in work that involved leaving the home. For instance, one woman who was particularly emphatic stated, "I don't want to go shopping, I don't want to go and do something. I don't like to go outside. He is good with that...and whatever he gets, it is good, I do not complain." Several of the same women expressed a preference not to develop skills such as driving a car or dealing with store personnel. In contrast, some women, particularly the two youngest women in the study, expressed strong positive feelings toward shopping, particularly for consumer goods like clothes and jewelry. These women associated shopping with the feeling of fitting in with their adopted country and in one case a woman was particularly proud to report that her shopping had resulted in the accumulation of credit card debt. The women who enjoyed entering the "outside world" tended to occupy a higher class location than the other women. As will be discussed in the following section, the extent to which women controlled how resources are allocated was one way that women in this study asserted their class location.

In total, the narratives that women provided with respect to their entrance into the labor market and the strategies that they used to meet the demands of work and 
domestic responsibility suggest that women rely on social networks in important ways and that social networks provide assistance in helping women find jobs and meet domestic demands. In addition to social networks, women in this study relied on a broad range of strategies that continually shifted and adjusted to changing conditions. Women proved to be remarkably adaptable to changes and resourceful in devising new approaches to the challenges they encountered.

\section{Income and Empowerment}

The extent to which a woman has control over how household resources are used is treated in this study as an approximation for empowerment. Out of concern of imposing western feminist ideals of empowerment, this analysis was embedded in the historical narrative that women shared regarding their natal household, the role that their mothers had in the household, and the extent to which the women's mothers were able to influence how household resources were allocated. By examining how women in this study remembered their mother's influence over household decisions it was assumed that women would contextualize their own influence in this sphere in relation to their mothers. There were many differences between daughters and mothers, particularly with respect to employment outside of the home. Two women in this study reported that their mothers worked outside of the home and the remaining mothers worked within the home. Several women reported that their mothers hired other women to help them with domestic responsibilities, something that none of them had considered doing. 
While no woman asserted full control over household resources, with the exception of the woman whose mother was divorced, some of the women's mothers were perceived as having a great deal of influence in how household resources were allocated while other mothers were considered to have very little control. The difference in the amount of control mothers were perceived as having in the household was attributed to the perceived value of their contributions to the household. Household labor in Ethiopia and Eritrea did not emerge as being highly valued and as a result women who stayed at home had less bargaining power and less control over how household resources were used than women who worked outside of the home.

An area where many women felt that their mothers had a high level of control was in determining how children would be cared for and how resources would be used for their education. As mentioned previously, women reported that their mothers and fathers directed resources towards the education of both male and female children. As mentioned previously, a number of women reported that their mothers strongly encouraged them to gain an education, and the education of children was considered to be among the most important priorities in a household.

While every woman reported that their mothers had a lot of influence with respect to child rearing, fewer women felt their mothers had control over resources that were directed towards household management. The ability to hire another woman to assist with household labor was interpreted as an indication that the mother had a high level of influence in directing household resources. Unlike in the United States, hiring women to help with household labor is not necessarily indicative of a high class 
location, as one informant indicated, "even if a woman does not work [outside the home], there is someone to help her, a maid; you do not have to be rich to have maids because women don't have jobs so they will work for you for two or three hours for a little money." Women from affluent households referred to hired household help as being permanent, while women from less affluent households indicated that their mothers did not regularly depend on the labor of others. This suggests that women from more affluent households had more control over household resources compared to women from less affluent households. This is further supported by one narrative account which revealed that one woman, whose family owned a large amount of land in a rural region of Ethiopia and depended on Wilaca, which were described as being similar to the untouchable caste in India, to do much of the household labor while the mother did little cleaning and limited her household work to taking care of children and cooking: "...she took care of the children, she had babies, and she would cook."

Among women of a less affluent class whose mothers worked inside the home, the ability to occasionally hire help was the extent of the control that women had over the allocation of household resources. Women reported that when their mothers wanted to buy something, they asked their husbands for money. Fathers made decisions, both major and minor, that affected the household. One woman, when asked how decisions were made in her natal household responded that her mother, "She had to ask, "Can I have money? Can I do this? And my Dad, he decides everything. He does not ask." In contrast, women whose mothers worked outside of the home indicated that their mothers had more influence in household decisions and were able 
to direct how resources were allocated. For instance, one woman's mother made the decision that the entire family would immigrate to the United States. She applied for the paperwork, filled out the forms, and paid the necessary fees. Mothers who worked outside of the home relied heavily on hired women to cook, clean, and care for children, and in turn their work outside of the home provided them with an improved bargaining position within the household.

The women interviewed agreed that in general, women in Ethiopia and Eritrea have very little control over their income, little access to employment or educational opportunities, and little influence over household decisions. When their own experience did not match these expectations, as when mothers did assert their opinion, file the forms for emigration, or work outside of the home, women indicated that this was an exception. In contrast, women expressed feelings that here, in the United States, women and men should be equal and have equal influence in household decisions. Many women claimed that their husbands helped equally with household labor and that they had equal say in household decisions: "We make decisions together. We always want to do the same thing, we always chose the same." Women attributed this change in attitude toward women on the part of men to a range of factors. Some of these factors reflected how the change in location increased women's freedom and improved their rights. But a key change in men's attitudes was a result of how women perceived their contribution to the household economy. Women's employment outside of the house provided them with an improved negotiating position, as is captured in this quote by a woman who works with the community and 
helps new immigrants and refugees adjust to the United States: "Men may not want to help initially, and most of them don't initially. Later on they will have to because she is going to earn money and she is going to insist."

The influence that women could wield in negotiating household decisions was limited, as was evidenced by several cases where women admitted that their influence did not extend to "big" decisions such as buying a house or living in a particular location. In one case a daughter of a woman described how her mother, after making the decision that her family would emigrate and deciding where in the United States the family would live stopped making decisions entirely after making a "mistake," as is illustrated by the following: "When we first got here and needed to buy a car, and my Mom and Dad decided to go shopping for a car. My Dad came up with one that was reasonable, but my Mom, she was unsatisfied and decided that, since she was paying for it, she wanted to have a nice car so she picked out a very expensive car. This was a turning point. Up until then, my Mom had been making decisions, but with this she made a mistake. The car was very expensive and now we are paying for it. She stopped making decisions after that."

In terms of negotiating the division of labor within the household, women reported that their husbands did far more housework than men in Ethiopia or Eritrea, and many women claimed that household labor was equally shared. When pressed however, women revealed that the division of labor in the household was far more weighted toward women remaining responsible for the bulk of cooking, cleaning, and childcare, while men often did the shopping, as was discussed previously. One 
woman, explaining that her husband helps with "everything" suggested that an equal division of household labor was not always the case: "Some men, they want it just like it was back home. I know, I was engaged two times to men who wanted me to do everything and I said no. But my fiancé is different. I am lucky. Many of my friends have it worse than me...[They] are married to men who come here and after 20 years they still won't even make tea or coffee for themselves. And if their wives ask them to do something, they say, "What, have you become an American now?"' This suggests that some women in this study might have suggested that their husbands do more household labor than is actually the case out of an expectation that this was the desirable response.

Having the ability to influence household decisions and share household labor was closely related to women having control over their income. Generally, women who were able to negotiate a more equitable division of labor were also able to negotiate more influence over household decisions and maintain more control over their income. It was suggested by the data that women who had recently married were more likely to maintain control over their income and consider this an important issue compared to women who had been married for a longer time. This was illustrated by one woman in the study who had recently married and was relying on her savings from before her marriage to remit to her family while she looked for work. She did not feel that she could lay claim to her husband's income for this purpose and hesitated to spend her husband's income on herself. She anticipated unease over having to ask her husband for money to send to her family even after finding employment, especially if 
she was unable to maintain control over her income: "In the future, of course I am going to ask [to allocate remittances for her natal family]. When you work it is easier, even though you have to ask him, it is still your money!"

It was suggested that the ability to control income after marriage influenced how much money was allocated to natal households. One woman, who works extensively with immigrant and refugee Ethiopian and Eritrean communities stated that which family, whether the husband's or wife's, is prioritized in the sending of remittances is affected by the perceived contribution that each member makes to the household: "If she [the wife] is not working, then there would not have enough money, [and only the husband's family would receive remittances], but if there is money she can say I am going to build a house as big as your family's house for my mother and father. She has bargaining power." This informant went on to say that in $99 \%$ of households women do not maintain a bank account with their name on it and that the husband maintained final control over how resources are allocated.

Women who were recently married were more inclined to strategize to maintain control over a portion of their income, while in contrast, women how had been married and living in the United States for more than ten years reported that they pooled their income with their husband and that all household expenses, including remittances to extended family members, were taken out as needed. These women did not appear to attach a sense of importance to having control over their own income; rather several women expressed feelings of gratefulness to their husbands and a sense that they had "made it." This was understood to mean that they felt that they had 
survived through a difficult time with their husband, and that after working and living in the United States, had achieved a social location that they were satisfied with.

\section{Conclusion}

This research had, as its goal, the aim of exploring how migration and employment affects women's bargaining position within the household. This study demonstrated that immigration to the United States improved the opportunities for women in terms of education and employment. Beyond having left behind unstable circumstances and the benefits of living in a stable, wealthy country, women expressed the feelings of hope and possibility that has become part of the mythical narrative of immigrants to America. These feelings were often associated with their children's future: "Coming to America was like a dream come true. In America the children could have the opportunity to work, to do something with themselves." But even among the women who did not have children, the opportunities for education and employment as a means of improved class location emerged as highly important. All of the women without children who were in school or were strategizing on ways that they could go back to school so that they could obtain a better job. Women with children often currently worked or had worked in the past at multiple jobs in order to support their children and provide them with additional educational opportunities.

These benefits transferred to the natal family, especially when women emigrated prior to marriage. Women in this study expressed feelings of responsibility for financially supporting parents, if not the broader community, although the longer women stayed in the United States the less pressing was their feeling of needing to 
support family and extended kin. This finding suggests that migration of daughters is a viable strategy for households in Ethiopia and Eritrea to employ when trying to maintain their class location admits conflict, political instability, and a lack of economic development.

In terms of employment, women utilized social networks to both find job opportunities and to help meet the demands of household labor. Furthermore, income from employment helped improve women's bargaining position within the household. Women in this study were able to assert greater control over household resources and influence household decisions compared to their mothers. As women and men negotiate the division of household labor and as men participate more in this labor it was suggested by the data that men began to value the contributions that women made to household management more. This also improves the relative position of women within the household because their perceived contribution to the household increases. Women engaged in a range of strategies to meet the demands of the household while employed outside of the home. In addition to accessing other households in the immigrant community through which women could combine their resources to meet domestic demands, women also found employment opportunities that allowed them to combine their childcare responsibilities with their employment, and enlisted the assistance of parents who would come and live with their daughter to help care for her children. Husbands were identified with helping with some aspects of childcare and household labor, but generally they limited their assistance to work that took them outside of the home. 


\section{Chapter V}

\section{DISCUSSION AND CONCLUSIONS}

This research project was designed to answer three research questions that were developed to create a context for understanding how migration and employment affect women's empowerment. The first question asked who immigrant women were supporting through their labor; the second question asked how immigrant women found employment and what strategies women used once employed to meet the competing demands of household responsibilities and employment; and the third question asked to what extent women felt that they were able to maintain control over their income and influence household decisions. In this chapter, a summary of the findings are presented, these findings are the theoretical context that was developed in the review of the literature. Areas for future research are suggested and the limitations of the current research project are delineated.

\section{Summary of Findings}

With respect to who immigrant women are supporting through their participation in the labor market, this research found that women's income is used to support their households in the United States, as well as their natal households in Ethiopia and Eritrea. Some women reported that in addition to their parents, additional extended kin and occasionally community members that remained in Ethiopia and Eritrea depended upon them for support. Responses varied, depending in part on when women had married, either prior to emigration or afterwards, and on how long they had been married and living in the United States. Women who married after migrating were more likely to express that they felt responsible for supporting their natal 
household and extended kin and community members. Likewise, women who had been married for less time and had lived in the United States for a fewer number of years were also likely to feel greater responsibility for supporting households in Ethiopia or Eritrea. This suggests that migration is a useful strategy for households in the developing world to utilize to help stabilize their class location. This finding was supported by Gamburd's (2000) research, which also found that households utilize migration as a survival strategy, and that natal households benefit more when women migrate prior to marriage.

Many women in this study reported that they migrated to the United States at the suggestion of their family. Reasons provided for migration included a desire to gain an education and to access employment opportunities that were unavailable to women in Ethiopia and Eritrea. The overreaching factor that encouraged women to migrate was the desire to leave an area that was engaged in a long conflict and where political, economic and social instability persisted.

Women utilized social networks to identify employment opportunities and once employed, depended on social networks as well as a range of other strategies to meet the demands of the household and employment. These networks primarily consisted of extended family networks and helped newcomers adapt to changes in social structure while also serving as a resource for immigrants. The most important function of social networks that emerged from this data was in the capacity of networks to provide women with additional strategies to negotiate childcare and household labor, which enabled them to work outside of the home. These networks were combined with non-standard shifts and were key strategies that women, and men 
to a lesser extent, used to meet the demands of household responsibilities. Other strategies that women used to meet the demands of childcare included finding employment that allowed them to care for their children while working and having the woman's mother come from Ethiopia or Eritrea to care for young children.

Influencing household decisions and maintaining control over income was the most controversial area that this research broached. Immigrant women felt that they had more control over income and more influence in the household than their mothers. Again, the length of time that women had been married and how long they had lived in the United States had an impact on how much control they felt they needed and had over their income. Women who had lived here for longer than ten years and had been married for nearly as long felt that income and household resources should be combined and expenditures could be taken out of this joint account. Additional interviews suggested though that it was unusual for women to have their name on a “joint" bank account. Among women who were more recent immigrants and who had been married for fewer years, control over income was at the forefront of their mind with respect to household relations. Some women expressed the feeling that without adequate control over their income they would be unable to support their natal family adequately. For women who had lived here for less time, having control over income translated in having buying power in the consumer market. Women felt they had control over their income when they could purchase goods for themselves and their children, but when pressed, it emerged that this control over income was often limited to smaller purchases and larger purchases required their husband's approval. 
Several women indicated that within their household, gender relations approached a level of equality not found in Ethiopia or Eritrea. But when pressed to discuss issues relating to the influence women had in household decisions or how household labor was divided, it became apparent that equality was still something women were working towards. What did emerge that was promising was that as women engaged in paid work outside of the house and pressure was placed upon husbands to help with domestic work, the perceived contribution of women was increased. Sen argues that a person's bargaining position within a household is determined in part by their perceived contribution to the household, and this was supported by this research. As the value of women's labor increased, and as men acknowledged the work that women did in the household, there was a corresponding increase in the influence that women could assert in household decisions. This suggests support for the overall finding of this research that participation in the labor market, while increasing the amount of work that women do and the amount of responsibilities women have, also improves women's negotiating position within the household.

\section{Suggestions for Future Research}

This research limited its line of inquiry to the affect that migration and employment has had on women's empowerment in households. Throughout the data gathering process, additional topics emerged that were also relevant to understanding how global structures are affecting female empowerment. One area of research that was particularly interesting was the affect that ongoing conflict has had on Ethiopian and Eritrean societies. Women who were interviewed for this project repeatedly 
referred to major changes that were occurring in Ethiopia and Eritrea, particularly with respect to women's role in their societies. Women fought "on the front lines of battle" and informants contribute this as having an effect on how women are currently valued in their countries.

In this paper, social location was discussed specifically with respect to the dimensions of class and gender. Throughout the interviewing process, informants referred to major ethnic schisms that were developing in the Portland Ethiopian and Eritrean communities that did not exist in Ethiopia or Eritrea. These schisms between ethnic groups were broadening divisions in the community, which were believed to be decreasing the political power that this community could have if united. Many of the women indicated that the schisms were a result of people from rural Ethiopia or Eritrea immigrating to the United States. Because rural people seldom encountered other ethnicities in their native country, upon arriving in a more metropolitan area these immigrants constructed barriers. These barriers then make social networks less effective since they limit the pool of potential connections.

\section{Limitations of the Research}

Conducting research across race and ethnic categories entails confronting several challenges that can lead to significant limitations. Methodologists have long acknowledged that the assumptions of one culture regarding concepts such as masculinity and femininity do not translate well into other cultural gender role developments (Stanfield 1994). In this study efforts were made to remain open to different cultural assumptions regarding gender. Women were encouraged to define agency in their own culturally relevant ways. But there were often assumptions made 
that I might be unaware of. Furthermore, women who participated in this study might have answered questions in a way that they felt was socially desirable and not reflective of their own experience.

While attempts were made to maximize the range of women in this study to reflect different ethnic groups, class, and time spent in the United States, the success of these efforts were limited in significant ways by an inability to interview women who had not become proficient in English, and to a lesser extent by a limited success in gaining access to Ethiopian and Eritrean women who did not have jobs that put them in direct contact with the public. For these reasons, this sample consists of a disproportionate number of women who lived here longer than five years and who work in sectors that put them into contact with the public, such as restaurants and markets. 


\section{WORKS CITED}

Agarwal, Bina. 1997. "Bargaining" and Gender Relations: Within and Beyond the Household." Feminist Economics 3(1): 1-51.

Becker, Gary S. 1981. A Treatise on the Family. Cambridge, MA: Harvard University Press.

Beneria, Lourdes. 2003. Gender, Development, and Globalization Economics as if All People Mattered. New York: Routledge.

Benería, Lourdes and Martha Roldán. 1987. The Crossroads of Class and Gender. Chicago: The University of Chicago Press.

Benería, Lourdes and Gita Sen. 1986. "Accumulation, Reproduction, and Women's Role in Economic Development: Boserup Revisted." Pp. chapter 9 in Women's Work, edited by Leacock and Safa. New York: Gergin and Garvey.

Boyd, Monica. 1989. "Family and Personal Networks in International Migration: Recent Developments and New Agendas." International Migration Review 23:638-670.

Brink, Benjamin. 2005. "On Northeast Martin Luther King." The Oregonian, 20 October, 16.

Castles, Stephen and Mark J. Miller. 2003. The Age of Migration, $3^{\text {rd }}$ edition. New York: The Gulford Press.

Chen, Hsiang-shui. 1992. Chinatown No More Taiwan Immigrants in Contemporary New York. Ithaca: Cornell University Press.

Cherlin, Andrew J. 2002. Public and Private Families: An Introduction. Boston: McGraw Hill.

Chestnut, Clifton. 2003. "Toil, Talent and Triumph- Two Brothers, Ethiopian Refugees, Tackle English, Shine in School and on to Top U.S. Universities." The Oregonian, 27 April,1A.

Chuang, Angie. 2002. "Immigrant's Unionizing Efforts Pay Off. “ The Oregonian, 28 January, 2B.

------ 2003. "Finding Common Ground." The Oregonian, 17 September, 1C. 2004. "Catching a City's Many Views." The Oregonian, 26 July, 2B.

Central Intelligence Agency. 2005. "The World Factbook." Washington, DC: The Central Intelligence Agency. Retrieved October 1, 2005 (http://www.cia.gov/cia/publications/factbook/)

Deere, Carmen Diana and Magdalena Leon. 2001. Empowering Women. Pittsburg, PA: University of Pittsburg Press.

Donnelly, Nancy D. 1994. Changing Lives of Refugee Hmong Women. Seattle: University of Washington Press.

Espiritu, Yen Le. 1999. "Gender and Labor in Asian Immigrant Families." American Behavioral Scientist 42: 628-47.

Folbre, Nancy. 1986. "Cleaning House: New Perspectives on Household and Economic Development." Journal of Development Economics 22:5-40.

Folbre, Nancy. 1994. Who Pays for the Kids? Gender and the Structures of Constraint. London: Routledge. 
Gamburd, Michele Ruth. 2000. The Kitchen Spoon's Handle: Transnationalism and

Sri Lanka's Migrant Housemaids. Ithaca: Cornell University Press.

Hondagneu-Sotelo, Pierrette. 1999. "Introduction: Gender and Contemporary U.S.

Immigration." American Behavioral Scientist 42: 565-576.

Hugo, Graeme. 1994. "Migration and the Family." United Nations Occasional Papers

Series, No. 12.

Kabeer, Nalia. 2000. The Power to Choose. London: Routledge.

1998. "Cleaning House: New Perspectives on Household and Economic

Development." Journal of Development Economics 22:5-40.

Kandiyoti, Deniz. 1998. "Gender, ower and Contestation." In Feminist Visions of

Development, edited by Cecile Jackson and Ruth Pearson. London: Routledge.

1988. "Bargaining with Patriarchy." Gender and Society 2(3): 274-290.

Lofland, John and Lyn H. Lofland. Analyzing Social Settings. New York: Wadsworth Publishing Company.

McElroy, Marjorie and Mary Jean Horney. 1990. "Nash-Bargained Household

Decisions: Reply." International Economic Review 31(1): 237-42.

Menjívar, Cecilia. 1999. "The Intersection of Work and Gender." American

Behavioral Scientist 42: 601-27.

Miller , William L. and Benjamin F. Crabtree. 2004. "Depth Interviewing." In

Approaches to Qualitative Research, edited by Sharlene Nagy Hesse-Biber and

Patricia Levy. New York: Oxford University Press.

Min, Pyong Gap. 1998. Changes and Conflicts Korean Immigrant Families in New

York. Boston: Allyn and Bacon.

Nash, John. 1950. "The Bargaining Problem." Econometrica 18(2): 155-62.

Pessar, Patricia R. 1999. "Engendering Migration Studies." American Behavioral

Scientist 42: 577-600.

Polanyi, Karl. 1944. The Great Transformation. New York: Farrar and Rinehart.

Portes Alejandro and Rubén G. Rumbaut. 1996. Immigrant America, $2^{\text {nd }}$ edition.

Berkeley: University of California Press.

Sacks, Karen Brodkin. 1989. "Toward a Unified Theory of Class, Race, and Gender." American Ethnologist 16:534-550.

Salaf, Janet W. 1990. "Women, the Family and the State: Hong Kong, Taiwan, Singapore- Newly Industrialized Countries in Asia." In Women, Employment and the Family in the International Division of Labor, edited by Sharon Stichter and Jane L. Parpart. Philadelphia: Temple University Press.

Salifilios-Rothschild, Constanina. 1992. "Socio-economic Determinants of the

Outcomes of Women's Income-Generation in Developing Countries." In

Women, Employment and the Family in the International Division of Labor, edited by Sharon Stichter and Jane L. Parpart. Philadelphia: Temple University Press.

Samuelson, Paul A. 1956. "Social Indifference Curves." The Quarterly Journal of Economics, 70(1):1-22.

Sassen, Saskia. 2003. "Strategic Instantiations of Gendering in the Global Economy." In Gender and U.S. Immigration: Contemporary Trends, edited by Hondagneu-Sotelo. Berkeley: University of California Press. 
---2002."Counter-geographies of Globalization: Feminization of Survival." In Feminist Post-Development Thought, edited by Kriemild Saunders. London: Zed Books. 1998. Globalization and Its Discontents. New York: The New Press.

Sen, Amatrya K. 1990. "Gender and Cooperative Conflicts." In Persistent Inequalities, edited by Irene Tinker. New York: Oxford University Press.

Shin, David H. and Thomas Ofcansky. 2004. Historical Dictionary of Ethiopia. Lanham, MD: Scarecrow Press.

Stanfield II, John H. 1994. "Ethnic Modeling in Qualitative Research." In Handbook of Qualitative Research, edited by Norman K. Denzin and Yvonna S. Lincoln. London: Sage Publications.

United Nations. 1999. "World Survey of the Role of Women in Development." Department of Economic and Social Affairs.

United States. Department of Homeland Security. 2006. Yearbook of Immigration Statistics: 2004. Washington, D.C.: U.S. Department of Homeland Security, Office of Immigration Statistics.

Wolf, Diane Lauren. 1992. Factory Daughters: Gender, Household Dynamics, and Rural Industrialization in Java. Berkeley: University of California Press.

Wolf, Diane L. 1997. "Daughters, Decisions and Domination: An Empirical and Conceptual Critique of Household Strategies." In The Women, Gender, \& Development Reader, edited by Nalini Visvanathan, et al. London: Zed Books.

Wright, Eric. 1997. Class Counts: Comparative Studies in Class Analysis. Cambridge: Cambridge University Press.

Zavella, Patricia. 1991. "Mujeres in Factories Race and Class Perspectives on Women, Work, and the Family." In Gender at the Crossroads of Knowledge, edited by Micaela di Leonardo. Berkeley: University 


\section{APPENDIX A: Voluntary and Informed Consent}

\section{BE PART OF AN IMPORTANT PROJECT "How Migration and Employment Affects Female Empowerment"}

Kerry Greer, a graduate student in the department of Sociology at Portland State University is doing a research study on how migrating and working affects women's empowerment, looking specifically at women from East Africa.

\section{What Will I Have To Do?}

If you decide to take part in this project, I will ask you to talk to me for about 1 hour. The interview will be on these topics:

- Your experience of migrating to the United States

- Your experience of working in the United States

- How this has changed how you think about yourself

- How this experience has changed things in your life

\section{Are There Any Risks?}

I know that this information is private and some of the topics discussed might make you feel uncomfortable. If you agree to take part in this study, you do not have to answer any questions that you do not want to. And if you want to stop completely, you can. This would not be a problem. If you are upset after the interview and need to talk with someone you can call Dr. Veronica Dujon at 503-725-3926. She is my advisor and will be able to address your concerns.

\section{What Will I Get In Return?}

1. While I am unable to pay you for your time, I will be happy to pay for any food or beverages consumed during the interview.

2. If you require money for a bus to come to the meeting place, I will provide you with bus fare.

3. The information gained from the interview will be used to better understand the affect migration and employment has on women. This information could benefit future women who migrate and work in the United States.

\section{What Are You Doing To Protect Me?}

Your privacy is very important to me. We have done many things to protect you:

- I will not tell anyone if you take part in this study

- You will be interviewed where you feel most comfortable.

- What you tell me will be kept private to the extent allowed by law. (By "kept private" I mean that the names of people who take part in the study will not be given to anyone else. And it means that I will only reveal what you say in a way that no one could ever guess of know it was you who said it.) If, in the course of the interview you disclose that you are, or are intending to, harm yourself or others, I am ethically and legally required to notify the appropriate authorities.

- Only I will know what you say. If you found out about this project through a third party, neither that party or any other party will me made aware of what has been said. 
- Your name and other personal information, which we need in order to keep track of who I talk to, will be kept in a locked file cabinet or in a locked file on the computer so that no one other than myself will be able to see it. For example, this form (which has your name on it) will be kept in a locked file cabinet.

- When I write or talk about what I have learned in this study, I will leave things out so no one will be able to tell whom we are talking about.

\section{Any Ouestions?}

If you have any questions about this study, this form, or the interview, you can talk to me (Kerry Greer 503-998-2163). You can also contact the Chair of the Human Subjects Committee of Portland State University about your rights as a research participant (someone who takes part in a study). Hours are 9:00 am to 5:00 pm. The office is located at Portland State University, Cramer Hall, Room 111, 1721 SW Broadway, Portland, OR 97201. The telephone number is 503-725-4288.

\section{If I Sign, What Does It Mean?}

This is a consent form. Your signature below means that:

- You have read and understand what this form says.

- You are willing to take part in the study by talking with me in an interview.

- You know that you do not have tot take part in this study. And even if you agree, you can change your mind and stop at any time.

- If you found out about this study from a third party, you know that taking part in this study has nothing to do with your relationship with that party. If you agree to take part or if you say no, they will not know and it will not matter. They will treat you the same.

- You will get a copy of this form to keep for yourself.

$\overline{\text { Participant Signature } \quad \text { Date }} \overline{\text { Participant Name, Printed }}$

$\overline{\text { Interviewer Signature }} \quad$ Date $\quad \overline{\text { Interviewer Name, Printed }}$

\section{Permission To Record The Interview}

In addition, I would like permission to make an audio recording of our conversation so that I will be able to listen to it again at a later date. This recording will be kept in a secure location and will not be shared with anyone. By signing below you indicate that it is okay with you if I record the interview:

Participant Signature Date

